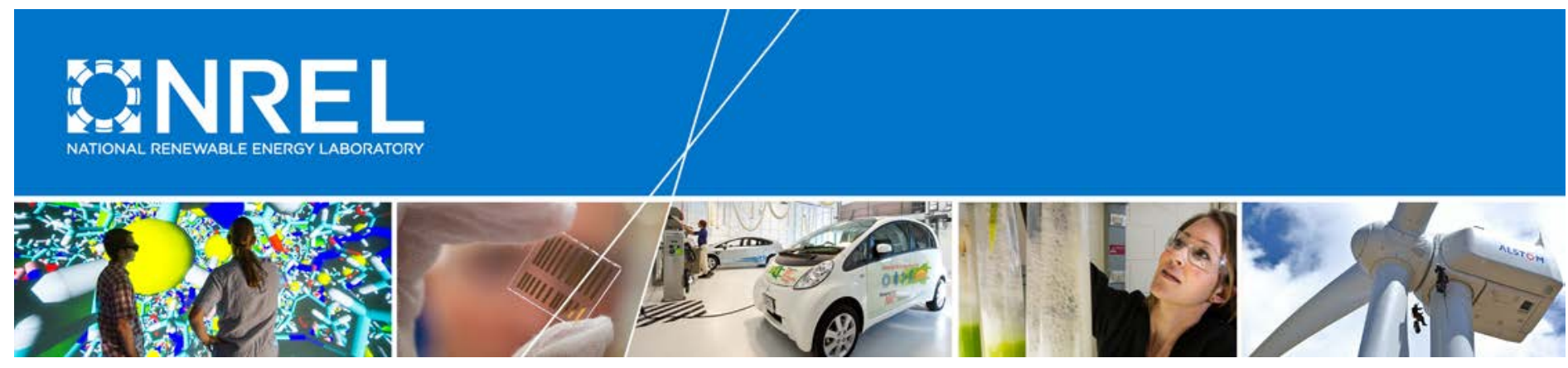

\title{
E15 and Infrastructure
}

K. Moriarty

National Renewable Energy Laboratory

J. Yanowitz

Ecoengineering, Inc.

Produced under direction of Renewable Fuels Association by the National Renewable Energy Laboratory (NREL) under Technical Services Agreement No. TSA 14-665 and Task No. WTJZ.1000.

NREL is a national laboratory of the U.S. Department of Energy Office of Energy Efficiency \& Renewable Energy Operated by the Alliance for Sustainable Energy, LLC

This report is available at no cost from the National Renewable Energy Laboratory (NREL) at www.nrel.gov/publications.

Strategic Partnership Project Report

NREL/TP-5400-64156

May 2015

Contract No. DE-AC36-08G028308 


\title{
E15 and Infrastructure
}

\author{
Kristi Moriarty \\ National Renewable Energy Laboratory \\ Janet Yanowitz \\ Ecoengineering, Inc.
}

Prepared under Task No. WTJZ.1000

NREL is a national laboratory of the U.S. Department of Energy

Office of Energy Efficiency \& Renewable Energy

Operated by the Alliance for Sustainable Energy, LLC

This report is available at no cost from the National Renewable Energy Laboratory (NREL) at www.nrel.gov/publications.

National Renewable Energy Laboratory 15013 Denver West Parkway

Golden, CO 80401

303-275-3000 • www.nrel.gov
Strategic Partnership Project Report

NREL/TP-5400-64156

May 2015

Contract No. DE-AC36-08G028308 


\section{NOTICE}

This manuscript has been authored by employees of the Alliance for Sustainable Energy, LLC ("Alliance") under Contract No. DE-AC36-08GO28308 with the U.S. Department of Energy ("DOE”).

This report was prepared as an account of work sponsored by an agency of the United States government. Neither the United States government nor any agency thereof, nor any of their employees, makes any warranty, express or implied, or assumes any legal liability or responsibility for the accuracy, completeness, or usefulness of any information, apparatus, product, or process disclosed, or represents that its use would not infringe privately owned rights. Reference herein to any specific commercial product, process, or service by trade name, trademark, manufacturer, or otherwise does not necessarily constitute or imply its endorsement, recommendation, or favoring by the United States government or any agency thereof. The views and opinions of authors expressed herein do not necessarily state or reflect those of the United States government or any agency thereof. 


\section{Acknowledgments}

This work was commissioned by Renewable Fuels Association, sponsored by BYO Ethanol Campaign. The National Renewable Energy Laboratory would like to thank staff from the following organizations for their time informing this report: Ken Boyce, Roland Reigel, and Edgar Wolff-Klammer, Underwriters Laboratory; Jeff Dzierzanowski, Source North America Corporation; Lorri Grainawi and Wayne Geyer, Steel Tank Institute; Robert Renkes, Petroleum Equipment Institute; Sullivan Curran, Fiberglass Tank and Pipe Institute; the U.S. Environmental Protection Agency Office of Underground Storage Tanks; Baker Northwest; Bravo; Cimtek; Clay \& Bailey; EMCO Wheaton; Franklin Fueling, Morrison Bros.; National Environmental Fiberglass; OPW; Universal Valve; Vaporless Manufacturing; and Veeder-Root. 


\section{List of Acronyms}

$\begin{array}{ll}\text { AHJ } & \text { authority having jurisdiction } \\ \text { CARB } & \text { California Air Resources Board } \\ \text { CFR } & \text { Code of Federal Regulations } \\ \text { E0 } & \text { pure gasoline } \\ \text { E10 } & 10 \% \text { denatured ethanol; } 90 \% \text { gasoline blendstock } \\ \text { E100 } & \text { pure ethanol fuel } \\ \text { E15 } & 15 \% \text { denatured ethanol, } 85 \% \text { gasoline blendstock } \\ \text { E25 } & 25 \% \text { denatured ethanol, } 75 \% \text { gasoline blendstock } \\ \text { E85 } & \text { marketing term for high-blend ethanol } 51 \%-83 \% \\ \text { EPA } & \text { U.S. Environmental Protection Agency } \\ \text { FDEQ } & \text { Florida Department of Environmental Quality } \\ \text { NACS } & \text { National Association of Convenience Store Owners } \\ \text { NREL } & \text { National Renewable Energy Laboratory } \\ \text { OSHA } & \text { Occupational Safety and Health Administration } \\ \text { OUST } & \text { Office of Underground Storage Tanks } \\ \text { PEI } & \text { Petroleum Equipment Institute } \\ \text { psi } & \text { pounds per square inch } \\ \text { RFA } & \text { Renewable Fuels Association } \\ \text { STI } & \text { Steel Tank Institute } \\ \text { STP } & \text { submersible turbine pump } \\ \text { UL } & \text { Underwriters Laboratories } \\ \text { ULSD } & \text { ultra-low sulfur diesel } \\ \text { UST } & \text { underground storage tank } \\ \text { vol\% } & \text { percent by volume } \\ & \end{array}$




\section{Executive Summary}

This paper addresses the compatibility of E15 (15\% denatured ethanol, 85\% gasoline blendstock) with equipment at refueling stations. Over the last decade, a tremendous amount of work by refueling equipment manufacturers, industry groups, and federal agencies has resulted in a long list of equipment that can be used with E15. This report addresses compatibility through a literature review, a summary of applicable codes and standards, review of equipment manufacturer products, and verification with manufacturers regarding which ethanol blends work with their products. Over time, the refueling equipment manufacturers have improved their sealing materials for compatibility with a wide range of fuels. Upgrading materials in equipment improves consumer safety and reduces the risk of releases to the environment.

It is often stated that tanks cannot be used to store E15, but this assumption is incorrect as the majority of installed tanks can store blends above E10. For many decades, underground storage tank (UST) manufacturers approved their tanks for blends up to E100, for example, all steel tanks and double-walled fiberglass tanks since the year 1990. Manufacturers of pipe thread sealants (pipe dope) used in UST systems have stated that their products have been compatible with ethanol blends up to E20 for many years. For those tanks with low ethanol blend certifications, the U.S. Environmental Protection Agency's (EPA's) Office of Underground Storage Tanks (OUST) issued Guidance - Compatibility of UST Systems with Biofuels Blends in 2011 to enable alternative compliance with federal code as UST systems are in use for decades. This guidance allowed tank manufacturers to issue letters stating the compatibility of their tanks with specific ethanol blends. All existing tank manufacturers have issued such letters, and the majority of installed tanks are compatible with E15. Additionally, all existing pipe manufacturers have Underwriters Laboratories (UL) listing for E100.

All fuel and vapor handling equipment at a station was reviewed to determine if it was certified by a third-party (such as UL) and if it was listed for specific ethanol blends. The aggregated list confirms there are UL testing standards available now for all gasoline-ethanol blends from $0 \%$ to $85 \%$ ethanol. Stations comprise approximately 60 pieces of equipment designed to move and control fuel and vapors. The function of most equipment is to prevent, detect, and contain releases. The equipment includes tanks; pipes; dispensers and associated hanging hardware (breakaway, hose, nozzle, and swivel); fill equipment; leak detection; overfill prevention; and vapor equipment. Some of this equipment is specifically covered by codes and standards while other equipment relies on sound design and manufacturing. Certain equipment types are typically UL listed - these include tanks, pipes, dispenser, hanging hardware, submersible turbine pumps, and shear valves. UL listing is not a requirement; some manufacturers simply prefer to have UL listings for their products. Manufacturers will select, which, if any, models they will list for ethanol blends above E10. A review was conducted with each manufacturer to determine compatibility with ethanol blends. There is an extensive list of E15 and E15+ compatible equipment available in the appendices.

A literature review going back 15 years was conducted to determine if there were any negative impacts during the multi-year deployment of E10 nationwide. No incidents of E10 causing releases (also referred to as leaks) from UST systems were identified. None of the reviewed literature noted any association between E10 and any specific UST release. The EPA OUST's Performance Measures' data on UST releases were reviewed, and as E10 was deployed 
nationwide, the trend was fewer UST releases. Anecdotal input solicited from infrastructure industry experts said that they knew of no published reports of releases caused by E10.

There are future opportunities for retailers to remove or replace their current equipment not necessarily related to continuous changes in motor fuel composition. Credit card companies are requiring retail fueling stations to update their dispensers to accept new chip and PIN secure credit cards by October 2017, at which time fraud liability would switch to station owners if they have not updated their equipment. This presents an opportunity to increase E25 UL-listed equipment through a retrofit kit if electronics are being upgraded to accommodate the new credit cards, or if a station owner must purchase a new dispenser, it could pay a minimal amount more for an E25 dispenser. If a new dispenser is purchased, this may also present an opportunity to upgrade to an E85 dispenser, but at significant additional cost. 


\section{Table of Contents}

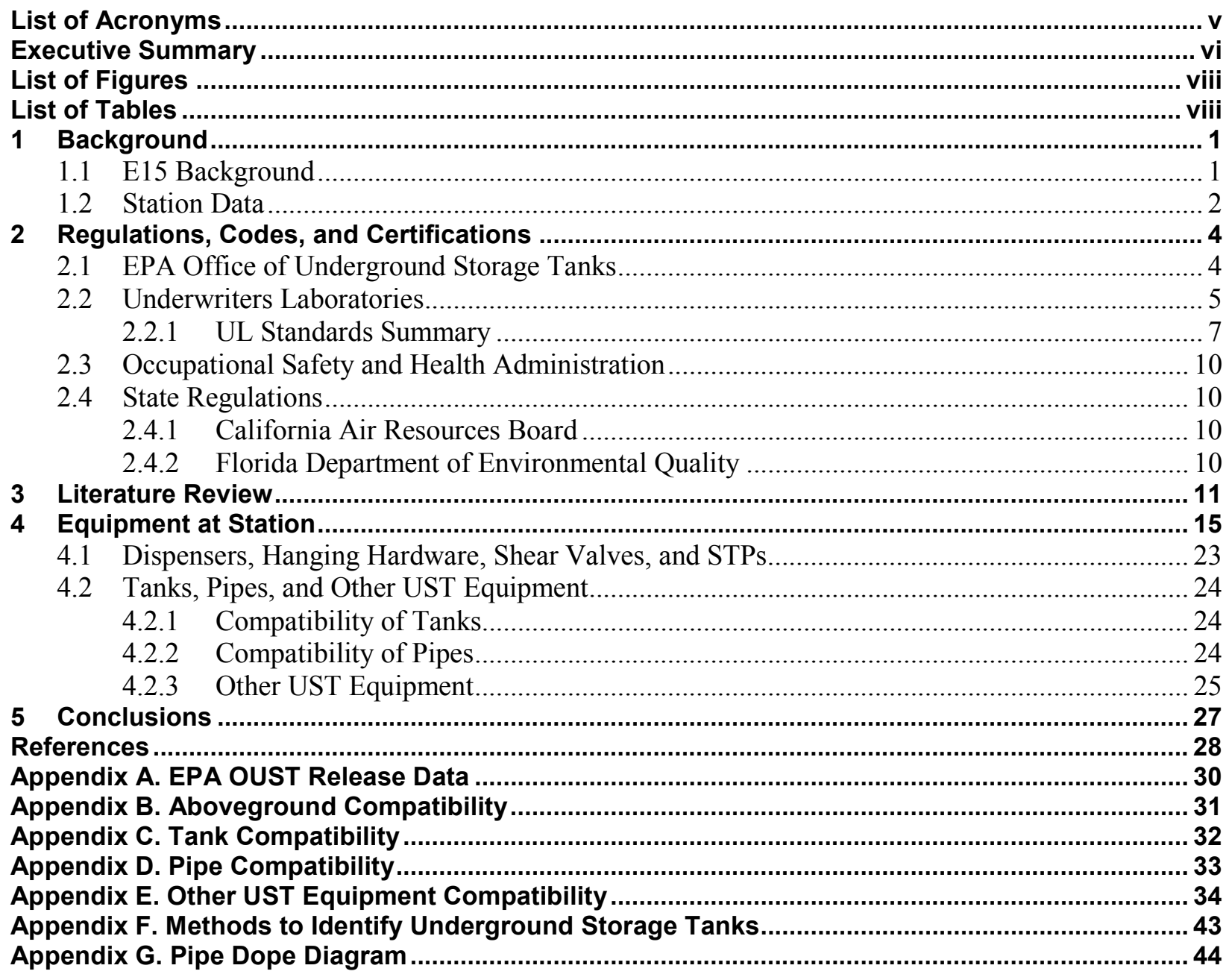

\section{List of Figures}

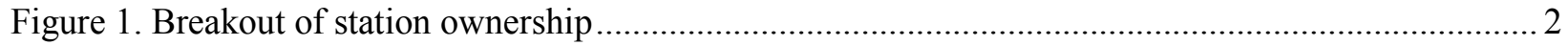

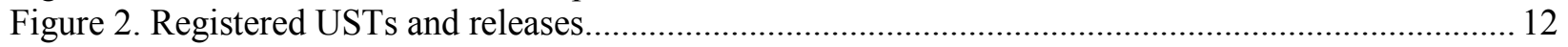

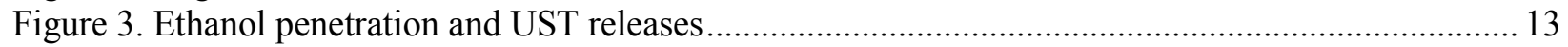

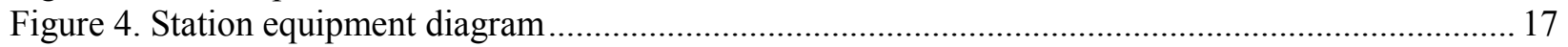

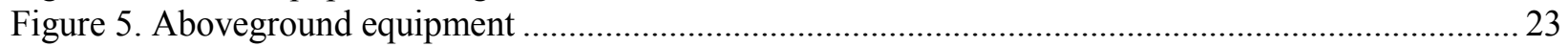

\section{List of Tables}

Table 1. Key UL Testing Standards for Refueling Equipment ............................................................. 6

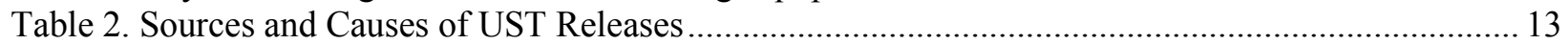

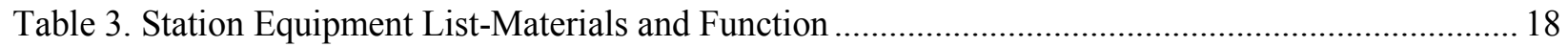




\section{Background}

\subsection{E15 Background}

In 2011, the U.S. Environmental Protection Agency (EPA) approved E15 for use in conventional light-duty cars and trucks model year 2001 and newer. ${ }^{1}$ As of the end of $2014,65 \%$ of the registered gasoline vehicles are 2001 and newer. ${ }^{2}$ EPA approved the Clean Air Act waiver based on significant testing and research (McCormick et al. 2013). EPA defines E15 as ethanol blends greater than 10 volume percent (vol\%) and up to $15 \mathrm{vol} \%$ ethanol. E15 is not widely available largely due to misinformation and retailer concerns. The primary concerns retailers have expressed include additional federal and state regulations to sell E15, misfueling liability, and the inability to meet the EPA's vapor pressure requirement for E15 in the summer.

Regulations to sell E15: There are several federal government requirements for selling E15 that do not apply to other fuel sold at stations. Federal regulations for a station to sell E15 include: an EPA E15 label on each dispenser selling E15, implementation of a misfueling mitigation plan, ${ }^{3}$ participation in a fuel quality survey (ensures dispenser is labeled and measures ethanol content and vapor pressure), product transfer documents for all deliveries of fuel for E15 use, and an approved dispenser/hose configuration. ${ }^{4}$ All requirements for E15 are available in the Renewable Fuels Association's (RFA's) E15 Retailer Handbook. ${ }^{5}$

Exposure to liability: Some stations owners have expressed concerns about misfueling of E15 into older vehicles. It is not uncommon for a consumer to be unaware of the model year of their vehicle. Under the Clean Air Act, any entity in the transportation fuel supply chain, including refueling stations, could be fined by the EPA up to $\$ 37,500$ per day for violations. The EPA has never fined a station this amount, and it has the authority under code to reduce the fine based on business size.

Vapor pressure: Blending of ethanol in to gasoline in the 10 to $15 \mathrm{vol} \%$ range typically causes the vapor pressure to increase by 1 pound per square inch (psi). ${ }^{6}$ The EPA regulates gasoline vapor pressure from June 1 to September 15 to reduce evaporative fuel emissions. In 1992, E10 received a 1-psi waiver, commonly known as the 1-pound waiver, from these requirements for non-reformulated gasoline areas. For purposes of the 1-pound waiver, E10 blends are defined as containing 9 to $10 \mathrm{vol} \%$ ethanol. The E10 1-pound waiver code is included in the Code of Federal Regulations which states that the waiver is for E10 only and not any other ethanol blend.

\footnotetext{
${ }^{1}$ E15 Notices \& Regulations. EPA. http://www.epa.gov/otaq/regs/fuels/additive/e15/e15-regs.htm

${ }^{2}$ Polk data 2014. Based on a total U.S. gasoline light-duty vehicle registration of 228 million of which 149 million are model year 2001 and newer.

${ }^{3}$ RFA developed Renewable Fuels Association Model E15 Misfueling Mitigation Plan, which was approved by EPA in March 2012 and is available free of cost to stations selling E15.

http://www.epa.gov/otaq/regs/fuels/additive/e15/documents/rfa-model-e15-misfueling-mitigation-plan.pdf

${ }^{4}$ For hose configurations, please review the EPA-approved Addendum: E15 Retail Advisory (updated 1/2013). Last accessed March 10, 2015: http://www.epa.gov/otaq/regs/fuels/additive/e15/documents/rfa-e15-retail-advisoryaddendum.pdf

${ }^{5}$ E15 Retailer Handbook. RFA. Accessed March 10, 2015: http://ethanolrfa.3cdn.net/643f311e9180a7b1a8 wwm6iuulj.pdf

${ }^{6}$ Vapor pressure is a method to measure the volatility of gasoline. Formerly known as Reid vapor pressure or RVP, today it is technically dry vapor pressure equivalent (DVPE) and is measured using ASTM Method D5191.
} 
E15 is not afforded the same 1-pound waiver and therefore cannot be sold in non-reformulated gasoline areas in summer months unless a lower vapor pressure hydrocarbon blendstock is used. ${ }^{7}$

\subsection{Station Data}

Overall, the total number of retail stations has declined over time, but approximately 1,600 new stations open annually (AFDC 2015, NACS 2014a). The following statistics from the National Association of Convenience Store Owners (NACS) 2015 Retail Fuels Report show some of the challenges in reaching various types of station owner and their ability to afford equipment upgrades and installations (NACS 2015):

- There are approximately 153,000 fueling stations.

- Fifty-eight percent are single-store owners/operators.

- Major oil companies own $0.4 \%$ of stations.

- Approximately $50 \%$ of stations sell branded fuel.

- Convenience stores sell $80 \%$ of transportation fuels. Hypermarkets (large grocery chains or merchandise stores) sell $14 \%$. The remainder of fuel is sold at low-volume locations like marinas.

- Sales per convenience store average 128,000 gallons per month (4,000 gallons/day).

- Transportation fuels are $71 \%$ of sales at a convenience store, but only $36 \%$ of profits.

- The average profit per convenience stores in 2013 was $\$ 55,000$ with most profit coming from selling products in the store.

One of the challenges in introducing E15 is reaching all the single-station owners. As evidenced in Figure 1, after single-store owners, the next highest percentage of ownership-17\% -is ownership groups with more than 500 stations.

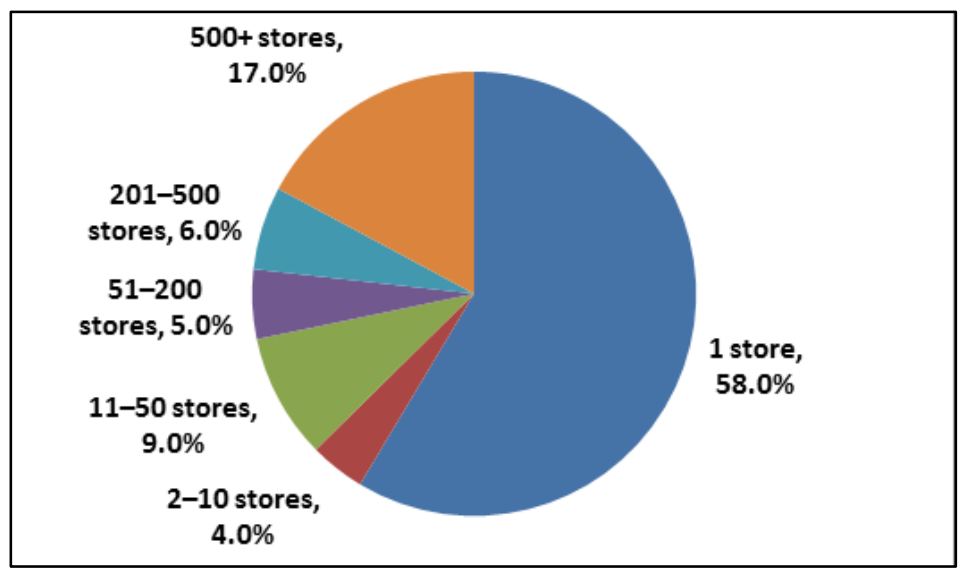

Figure 1. Breakout of station ownership

Source: 2015 Retail Fuels Report. NACS, 2015

\footnotetext{
${ }^{7}$ CFR 42 Chapter 85 Subchapter II Part A 7545 Regulation of Fuels (h) (4)
} 
Approximately $50 \%$ of convenience stores are branded by either an oil company (31\%) or refinery/distributor (19\%) (NACS 2014b). This ensures a market for oil and refinery company products and provides station owners with brand recognition. A contract typically lasts 10 years, and the terms will include sales volume requirements for fuels supplied, including regular and premium, and diesel if the station sells it. Due to sales volume requirements, there will be more challenges for branded stations to sell E15 than independent stations or convenience store chains. 


\section{Regulations, Codes, and Certifications}

In addition to the EPA requirements summarized in Section 1.1, E15 is subject to other regulations and codes that apply to other transportation fuels. There is no one entity that regulates all equipment at a station. Often times, the local authority having jurisdiction (AHJ) approves a station to sell a new fuel. "AHJ" refers to regulating organizations, offices, or individuals responsible for overseeing codes and standards and ensuring safety. Examples of AHJs include local fire marshals, state energy and environment offices, air and water boards, and similar organizations or offices. The most significant federal agencies overseeing some equipment at stations include EPA's Office of Underground Storage Tanks (OUST) and the Occupational Safety and Health Administration (OSHA). The Underwriters Laboratories (UL) role is significant in developing testing protocols and certifying refueling equipment for specific fuels.

Two organizations, the National Fire Protection Association (in particular, Code 30A, which includes language on alternative compliance to address new fuels) and the International Code Council, provide standard codes for retail stations that are accepted or modified to meet local requirements. Other organizations developing best practices and codes include American Petroleum Institute, Fiberglass Tank and Pipe Institute, NACE International, National Conference on Weights and Measure, National Leak Prevention Association, Petroleum Equipment Institute (PEI), and Steel Tank Institute (STI).

\subsection{EPA Office of Underground Storage Tanks}

EPA's OUST regulates tanks that store transportation fuels under Subtitle I of the Solid Waste Disposal Act states that a tank system must be compatible with the fuel stored. This code is currently under revision with a final rule expected in 2015. States administer the underground storage tank (UST) program, and compatibility is the responsibility of the tank owner.

The following critical components must be demonstrated as in compliance with federal code: tank (including tank lining); piping; line leak detector; flexible connectors; drop tube; spill/overflow equipment; submersible turbine pumps (STPs); sealants (pipe dope, thread sealant, fittings, gaskets, O-rings, bushings, couplings, boots); containment sumps; release detection floats/ sensors/probes; fill and riser caps; and shear valves.

Title 40 of the Code of Federal Regulations (CFR) Part 280-Technical Standards and Corrective Action for Owners and Operators of Underground Storage Tanks (UST), covers design, construction, and installation; operating requirements; release detection; release reporting; corrective action for releases; UST out-of-service and closures; financial responsibility (ability to cover the costs to clean up a release); and lender liability. It requires that tanks and piping be constructed, installed, and any portion that is underground and routinely contains product be protected from corrosion in accordance with a code of practice developed by a nationally recognized association or independent testing laboratory. It also requires that the UST be made of or lined with materials compatible with the regulated substance stored. There are requirements to have equipment installed to prevent releases, including the use of spill containment and overfill prevention equipment. There are also requirements to have equipment capable of detecting releases of regulated substances from the portions of the UST that routinely contain product. Since 1986, UST owners must submit documentation that a new tank has been installed 
along with certification of installation and keep maintenance records. UST owners must report all suspected and confirmed releases, generally within seven days.

40 CFR Part 281-Approval of State Underground Storage Tank Programs, and Part 282Approved Underground Storage Tank Programs, explain the requirements to authorize states to administer UST federal code under Subtitle I of the Resource Conservation and Recovery Act. 40 CFR Part 302 Designation, Reportable Quantities, and Notification, defines hazardous subjects stored in USTs (includes gasoline, ethanol, and many other chemicals), releases, and penalties.

In 2011, OUST released the Guidance - Compatibility of UST Systems with Biofuels Blends document, which provides an alternative path for demonstrating compliance with the compatibility requirements in federal code when storing biofuels above E10 or B20 (20\% biodiesel; 80\% petroleum diesel) (EPA 2011). OUST believes that while most biofuel blends are compatible with tanks and pipes, there could be issues with associated UST equipment. ${ }^{8}$ Tanks and associated equipment are in use for decades, and the guidance allows manufacturers to state compatibility with specific biofuel blends. This guidance is expected to be published in the CFR in 2015 after the Office of Management and Budget approves it. Incorporating this guidance into the CFR gives refueling station owners an added layer of security as it ensures their tank insurance is uncompromised, which is also an important factor in their ability to maintain a line of credit with their financial institution.

\subsection{Underwriters Laboratories}

UL is the primary third-party certification laboratory servicing the refueling equipment industry globally. UL develops testing standards by consensus and allows manufacturers time to comply. ${ }^{9}$ These standards have been available for many decades in the marketplace. There are many standards covering individual products in the fueling system and many different approaches to evaluating safety. The more recent standards address higher levels of ethanol and the introduction of biodiesel. Some standards comprehensively evaluate structural integrity, material compatibility, operating performance, and electrical safety while others may limit evaluations to specific items. In the past, some standards that provided listings for specific fuels were limited to petroleum products, but were then revised to handle low levels of ethanol blends. Over time, many UL standards provided the option for equipment manufacturers to list their products for gasoline and gasoline-ethanol blends with nominal ethanol concentrations up to 85\% (E0 - E85). While some UL standards allow manufacturers to select which fuel ratings to list for, there is trend towards revising standards to require equipment to be listed for all fuel types and blends that are commercially available. Testing is not conducted with commercial fuels. The trend is towards aggressive test fluids where gasoline is represented by Reference Fuel C (equal parts iso-octane and toluene) and it is mixed with ethanol, acid, and water. Table 1 summarizes the relevant refueling equipment UL standards. Information on applicable UL standards for each piece of refueling equipment at a station is described in Section 4 . Table 1 confirms that there are UL testing standards available now for all gasoline-ethanol blends from $0 \%$ to $85 \%$ ethanol content.

\footnotetext{
${ }^{8}$ Communicated by EPA OUST staff during a December 2013 call with National Renewable Energy Laboratory and Oak Ridge National Laboratory staff.

${ }^{9}$ The terms "UL listed" and "UL certified" can be used interchangeably.
} 
Table 1. Key UL Testing Standards for Refueling Equipment

\begin{tabular}{|c|c|c|}
\hline $\begin{array}{l}\text { UL Testing } \\
\text { Standard }\end{array}$ & Equipment Covered & Listing for Ethanol Blends \\
\hline UL 58 & Underground steel tanks & Does not list for specific fuels \\
\hline UL 1316 & Underground fiberglass tanks & E100 (non-aggressive test fluids) \\
\hline UL 971 & Pipes and pipe fittings & E100 (non-aggressive test fluids) \\
\hline \multirow[t]{3}{*}{ UL 2447} & $\begin{array}{l}\text { Sumps: tank, dispenser, transition, fill/vent } \\
\text { (spill buckets) }\end{array}$ & \multirow{3}{*}{$\begin{array}{l}\text { E85 (non-aggressive test fluids for } \\
\text { current listings). The new Standard } \\
2447 \text { requires testing with } \\
\text { aggressive E25 and E85. } \\
\text { Manufacturers must recertify by } \\
\text { June } 2016 \text {. }\end{array}$} \\
\hline & $\begin{array}{l}\text { Sump fittings: penetration, termination, } \\
\text { internal, test and monitoring }\end{array}$ & \\
\hline & $\begin{array}{l}\text { Sump accessories: cover, frame, } \\
\text { brackets, chase pipe }\end{array}$ & \\
\hline \multirow[t]{2}{*}{ UL 2583} & $\begin{array}{l}\text { Part I Vapor Control Products: emergency } \\
\text { vents, pressure vacuum vents, fill and } \\
\text { vapor adaptors, and monitor well caps }\end{array}$ & \multirow[t]{2}{*}{$\begin{array}{l}\text { Part I and Part II require testing with } \\
\text { aggressive E25, E85, B25, and } \\
\text { Reference Fuel F. }\end{array}$} \\
\hline & $\begin{array}{l}\text { Part II Liquid Control Products: overfill } \\
\text { protection (or prevention) valves, ball float } \\
\text { vent valve (or flow restriction device), drop } \\
\text { tubes, extractor tee, jack screw kit, face } \\
\text { seal adaptor (or threaded riser adaptor), } \\
\text { fill cap and adaptors }\end{array}$ & \\
\hline UL 87 & $\begin{array}{l}\text { Power-operated dispensing devices for } \\
\text { petroleum products }\end{array}$ & E10 (non-aggressive test fluid) \\
\hline UL 87A & $\begin{array}{l}\text { Power-operated dispensing devices for } \\
\text { gasoline and gasoline-ethanol blends with } \\
\text { nominal ethanol concentrations up to } 85 \% \\
\text { (E0 - E85) }\end{array}$ & $\begin{array}{l}\text { E25 and/or E85 (tests with } \\
\text { aggressive test fluids) }\end{array}$ \\
\hline UL 25 & $\begin{array}{l}\text { Meters for flammable and combustible } \\
\text { liquids and LP-gas }\end{array}$ & E10 (non-aggressive test fluid) \\
\hline UL 25A & $\begin{array}{l}\text { Meters for gasoline and gasoline-ethanol } \\
\text { blends with nominal ethanol } \\
\text { concentrations up to } 85 \% \text { (E0 - E85) }\end{array}$ & $\begin{array}{l}\text { E25 and/or E85 (tests with } \\
\text { aggressive test fluids) }\end{array}$ \\
\hline UL 79 & $\begin{array}{l}\text { Power-operated pumps for petroleum } \\
\text { dispensing products }\end{array}$ & E10 (non-aggressive test fluid) \\
\hline UL 79A & $\begin{array}{l}\text { Power-operated pumps for gasoline and } \\
\text { gasoline-ethanol blends with nominal } \\
\text { ethanol concentrations up to } 85 \% \text { (E0 - } \\
\text { E85) }\end{array}$ & $\begin{array}{l}\text { E25 and/or E85 (tests with } \\
\text { aggressive test fluids) }\end{array}$ \\
\hline UL 330 & $\begin{array}{l}\text { Hose and hose assemblies for dispensing } \\
\text { flammable liquids }\end{array}$ & E10 (non-aggressive test fluid) \\
\hline UL 330A & $\begin{array}{l}\text { Outline for hose and hose assemblies for } \\
\text { use with dispensing devices dispensing } \\
\text { gasoline and gasoline-ethanol blends with } \\
\text { nominal ethanol concentrations up to } 85 \% \\
\text { (E0 - E85) }\end{array}$ & $\begin{array}{l}\text { E25 and/or E85 (tests with } \\
\text { aggressive test fluids) }\end{array}$ \\
\hline UL 331 & $\begin{array}{l}\text { Strainers for flammable fluids and } \\
\text { anhydrous ammonia }\end{array}$ & E10 (non-aggressive test fluid) \\
\hline
\end{tabular}




\begin{tabular}{|c|c|c|}
\hline $\begin{array}{l}\text { UL Testing } \\
\text { Standard }\end{array}$ & Equipment Covered & Listing for Ethanol Blends \\
\hline UL 331A & $\begin{array}{l}\text { Strainers for gasoline and gasoline- } \\
\text { ethanol blends with nominal ethanol } \\
\text { concentrations up to } 85 \% \text { (E0 - E85) }\end{array}$ & $\begin{array}{l}\text { E25 and/or E85 (tests with } \\
\text { aggressive test fluids) }\end{array}$ \\
\hline UL 428 & Electrically operated valves & E10 (non-aggressive test fluid) \\
\hline UL 428A & $\begin{array}{l}\text { Outline for electrically operated valves for } \\
\text { gasoline and gasoline-ethanol blends with } \\
\text { nominal ethanol concentrations up to } 85 \% \\
\text { (E0-E85) }\end{array}$ & $\begin{array}{l}\text { E25 and/or E85 (tests with } \\
\text { aggressive test fluids) }\end{array}$ \\
\hline UL 567 & $\begin{array}{l}\text { Emergency breakaway fittings, swivel } \\
\text { connectors and pipe-connection fittings for } \\
\text { petroleum products and LP-gas }\end{array}$ & E10 (non-aggressive test fluid) \\
\hline UL 567A & $\begin{array}{l}\text { Emergency breakaway fittings, swivel } \\
\text { connectors and pipe-connection fittings for } \\
\text { gasoline and gasoline-ethanol blends with } \\
\text { nominal ethanol concentrations up to } 85 \% \\
\text { (E0 - E85) }\end{array}$ & $\begin{array}{l}\text { E25 and/or E85 (tests with } \\
\text { aggressive test fluids) }\end{array}$ \\
\hline UL 842 & Valves for flammable fluids & E10 (non-aggressive test fluid) \\
\hline UL 842A & $\begin{array}{l}\text { Valves for gasoline and gasoline-ethanol } \\
\text { blends with nominal ethanol } \\
\text { concentrations up to } 85 \% \text { (E0 - E85) }\end{array}$ & $\begin{array}{l}\text { E25 and/or E85 (tests with } \\
\text { aggressive test fluids) }\end{array}$ \\
\hline UL 2586 & Hose nozzle valves & E10 (non-aggressive test fluid) \\
\hline UL 2586A & $\begin{array}{l}\text { Hose nozzle valves for gasoline and } \\
\text { gasoline-ethanol blends with nominal } \\
\text { ethanol concentrations up to } 85 \% \text { (E0 - } \\
\text { E85) }\end{array}$ & $\begin{array}{l}\text { E25 and/or E85 (tests with } \\
\text { aggressive test fluids) }\end{array}$ \\
\hline
\end{tabular}

Source: UL

\subsubsection{UL Standards Summary}

\section{UL 1316, Glass-Fiber-Reinforced Plastic Underground Storage Tanks for Petroleum Products, Alcohols, and Alcohol-Gasoline Mixtures}

This standard covers underground fiberglass tanks and allows manufacturers to select in which of three fuel ratings to have their product listed. Essentially it is an "a la carte" menu. Both existing fiberglass tank manufacturers have UL listing for E100.

The test fluids used to evaluate compatibility for the three fuel ratings are:

1. Petroleum products: includes but is not limited to: regular and premium gasoline, diesel fuel, fuel oil, Reference Fuel C, kerosene, and fuel oil \#6 (option at elevated temperature)

2. Alcohol and petroleum blends: includes fuel \#1 plus E10 and E30. (This allows listing for E10 but not E30 despite testing with it.)

3. Alcohol and petroleum blends: includes \#1 and \#2 test fluids plus E15, E50, E100, and methanol blends at the same volumes. 


\section{UL 58, Standard for Steel Underground Tanks for Flammable and Combustible Liquids}

This standard covers underground steel tanks. It does not test or certify equipment for specific fuels but instead for flammable and combustible liquids. All existing U.S. steel tank manufacturers have UL listing under this standard.

\section{UL 1746, External Corrosion Protection Systems for Steel Underground Storage Tanks}

This standard provides certification for external corrosion protection systems applied to UL 58 steel tanks. There are four parts, and parts i (galvanic-type cathodic protection systems), ii (fiberreinforced plastic composite systems), and iv (polyurethane-coated systems) do not test with specific fuels; listing is for flammable and combustible liquids. Part iii (polyurethane, polyurea, high density polyethylene, or fiber-reinforced plastic jacketed systems) provides ethanol listing only for jacket tanks with secondary containment because there is an interstitial space formed by the jacket. The test requires 30 days of exposure to test fluid and includes the same testing fluids as UL 1316.

\section{UL 1856, Underground Fuel Tank Internal Retrofit Systems}

This standard allows a station owner to retrofit the existing tank onsite in three ways, all of which require the tank's internal surface to be refurbished prior to applying nonmetallic coatings with new fuel ratings. In the past, this standard allowed manufacturers to select which class of fuels to list for, the same as UL 1316. However, UL 1856 has recently been revised to require compliance with all automotive fluids, including E25 and E85, by June 14, 2017.

\section{UL 142, Aboveground Flammable Liquid Tanks}

This standard covers aboveground tanks, which are not very common at commercial fueling stations. It does not test or certify equipment for specific fuels but instead for flammable and combustible liquids. UL Standards 2080 and 2085 also apply to aboveground tanks for fire protection, as they require use of a UL 142 core tank.

\section{UL 971, Standard for Nonmetallic Underground Piping For Flammable Liquids, and UL 971A, Outline of Investigation for Metallic Underground Piping for Flammable Liquids}

This standard covers flexible and rigid piping and pipe fittings for both fuel and vapor. This standard has similar fuel ratings and uses similar test fluids as UL 1316. All existing pipe manufacturers have UL listing for E100.

\section{UL 2039, Outline of Investigation for Flexible Connector Piping for Fuels}

This standard covers flexible connectors that typically connect underground piping to other equipment in sumps. In the past, this standard offered the same selection of test fluids as UL 1316. The standard was updated in December 2010 to require all automotive fluids, including E25 and E85. 


\section{UL 2447, Containment Sumps, Fittings and Accessories for Fuels}

This standard covers containment sumps (dispenser, tank, transition, spill buckets) and all the fittings (termination, penetration, test/monitor, internal) and accessories (frames, brackets, chase, etc.). This standard previously and currently allows manufacturers to select test fluids from the same three classes as UL 1316. However, the standard has been updated, and manufacturers will need to demonstrate compliance with the standard and listing for all automotive fuels, including E25 and E85, by June 302016 (originally the date was June 30, 2015, but manufacturers asked for an extension). Some manufacturers list under this standard and others do not.

\section{UL 2583, Outline for Investigation for Fuel Tank Accessories}

This new standard covers equipment that may have been listed under other, older standards and also covers equipment that has never previously been listed by UL. Few manufacturers listed products under the old standards. This new standard requires manufacturers to list all automotive fuels, including E25 and E85. Part I was issued in June 2011 to cover all vapor control products - any functional device on tank top or directly fitting on or indirectly connected to a pipe to control vapors. Equipment covered includes emergency vents, pressure vacuum vents, fill and vapor adaptors, and monitor well caps. Part II was issued in June 2014 and covers liquid control products; specifically functional equipment designed to connect to tank top and to contain spills and prevent overfills. This covers overfill protection (or prevention) valves, ball float vent valves (or flow restriction devices), drop tubes (never previously listed by UL), extractor tees, jack screw kits, face seal adaptors (or threaded riser adaptors), fill caps, and adaptors.

\section{UL 87, Power-Operated Dispensing Devices for Petroleum Products, and UL 87A, Standard for Power-Operated Dispensing Devices for Gasoline and Gasoline/Ethanol Blends with Nominal Ethanol Concentrations up to 85 Percent (E0 - E85)}

UL 87 allows listing for up to E10 with minimal exposure to test fluids. In 2007, UL introduced UL 87A, Outline of Investigation for Power-Operated Dispensing Devices for Gasoline/Ethanol Blends with Ethanol Content Greater than 15 Percent to address E85. At the time, UL 87A covered additional testing for multiple pieces of related equipment. These standards work somewhat differently than those for tanks, pipes, and associated tank equipment. A manufacturer can select UL 87 for listing a product up to E10 or UL 87A to list a product for up to just E25 or opt to test and list it for E85 also. Since development of UL 87A in November 2012, equipment has been split out into different standards specific to each equipment type. (The designation "A" after a listing denotes the option to list a product for up to just E25 and/or E85).

- Breakaways, swivels, pipe connection fittings: 567/567A

- Dispensers: 87/87A

- Filters: 331/331A

- Hoses: 330/300A

- Meters: $25 / 25 \mathrm{~A}$

- Nozzles: 2586/2586A 
- Shear valve (emergency shut-off valve): 842/842A

- Submersible turbine pump: $428 / 428$ A

\subsection{Occupational Safety and Health Administration}

OSHA regulates some fuel-dispensing equipment. Its regulations applicable to service stations have not been updated in decades and therefore do not specifically address biofuels. OSHA is planning to update these standards to address new fuels in the marketplace.

OSHA 1910.106 (g)(3)(iv) and (g)(3)(vi)(a) require dispensers and nozzles to be listed by a third party for specific fuels.

OSHA 1910.106(b)(1)(i)(b) and (c)(2)(ii) require tanks, piping, valves, and fittings other than steel to use sound engineering design for materials used; however, there is no listing requirement. OSHA 1910.106(b)(1)(iii) covers steel tanks and requires sound engineering and compliance with UL 58 and American Petroleum Institute Standards 650 and 12B as applicable.

\subsection{State Regulations}

\subsubsection{California Air Resources Board}

The California Air Resources Board (CARB) is the division of the California Environmental Protection Agency tasked with reducing air pollutants. CARB developed test procedures for vapor recovery equipment and requires specialized enhanced vapor recovery equipment. The following equipment must be approved under this program: adaptors, drop tubes, hoses, nozzles, overfill protection devices, pressure vacuum vents, spill containers, and vapor return piping (CARB 2015). The requirements are not for equipment use with specific fuels.

\subsubsection{Florida Department of Environmental Quality}

The Florida Department of Environmental Quality (FDEQ) approves station storage tank equipment through state regulations (FDEQ 2015). The regulations require State of Florida approval of tank system equipment prior to installation or use, except for the following equipment: dispensers, islands, nozzles, hoses; monitoring well equipment; manhole and fillbox covers; valves; cathodic protection stations; metallic bulk product piping; small-diameter piping not in contact with soil unless the piping extends over or into surface waters; and vent lines. All other equipment must be approved through a third-party laboratory demonstration that provides a technical evalution of the equipment, test results verifying equipment functions as designed, and a professional certification that the equipment meets Florida performance standards (FDEQ 2015). The performance standards are straightforward and are not fuel specific. The State of Florida has a long list of approved equipment (FDEQ 2015). 


\section{Literature Review}

A literature review was performed to identify specific components or materials that have been associated with releases from USTs storing E10. The information is intended to be used to minimize the potential for future releases, particularly during the rollout of E15. The literature review was limited to releases identified during the years 2000 to the present. During the years covered by this literature review, the penetration of E10 into the U.S. gasoline pool went from minimal in many regions of the country to full saturation.

\section{Scope of Review}

The following sources were used:

- LUSTLine 2000 - present.

- PEI Journal 2009 - present (PEI Journal not available online before 2009).

- TulsaLetter (The TulsaLetter is the official e-newletter of PEI.) 2000 - present.

- Experts in refueling infrastructure were contacted, including EPA, Fiberglass Tank and Pipe Institute, PEI, STI, and oil industry representatives.

- EPA OUST release data website.

- Web search for literature and data on UST E10 releases.

\section{Major Findings}

- The number of reported UST releases has been steadily declining since 2000 from occurring in about 2\% of all USTs in the United States to about 1\% in 2014 (EPA 2015a).

- There is no evidence of different trends in the number of UST releases between states that were early adopters of E10 and states that only recently reached full saturation of E10.

- EPA has collected data on the source and cause of UST releases. Because of the high number of releases that were attributed to "unknown" or "other causes," the data cannot be considered conclusive, but roughly $10 \%$ of all releases were attributed to corrosion in a 2004 review and 7\% in 2009 (EPA 2004, Eigmey 2011).

- Anecdotal input solicited from infrastructure industry experts said that they knew of no published reports of releases caused by E10.

- None of the reviewed literature listed any association between E10 and any specific UST release.

Figure 2 shows the number of USTs declining over time which is a result of the declining number of retail stations. There were approximately 571,000 registered USTs in the United States as of September 2014 (EPA 2015a). ${ }^{10}$ OUST provides UST release data annually, and over the time that E10 spread across the country, the number of releases has tended to decline from $2 \%$ of registered tanks in 2000 to $1.2 \%$ of USTs experiencing a release in 2014. Figure 3

\footnotetext{
${ }^{10}$ A year is measured by the federal government's fiscal year from October 1 to September 30.
} 
shows that as E10 was deployed over the last several years, the number of UST releases did not increase. Any problems associated with introducing a different fuel at an existing station usually happen soon after storing a different fuel. In interpreting these results, it should be noted that many releases are discovered and reported years after they first occurred when the tank is removed from service. Other releases are due to operator errors (such as overfilling or poor maintenance) and may be completely unrelated to the fuel stored.

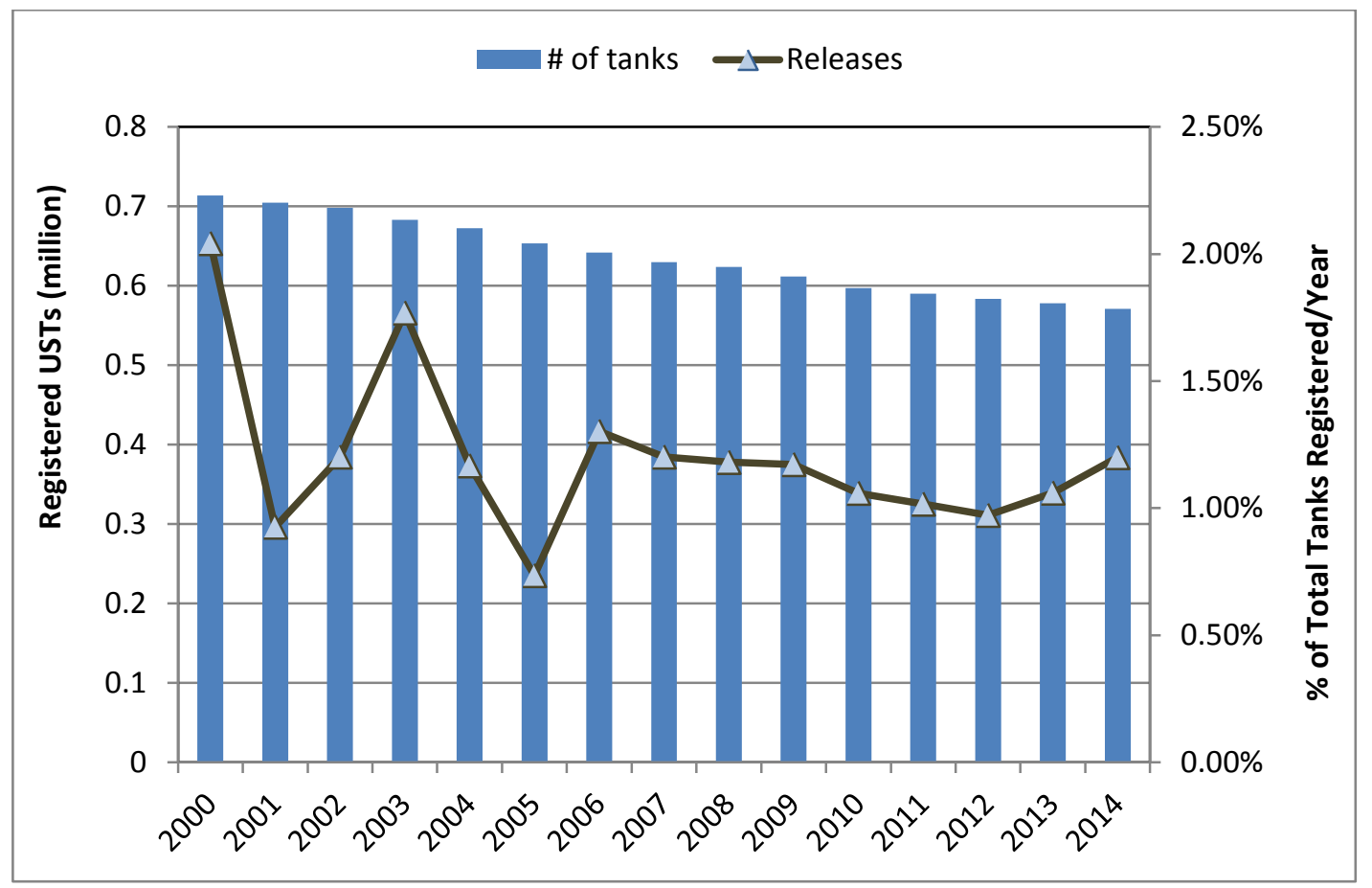

Figure 2. Registered USTs and releases

Source: UST Performance Measures. EPA OUST. Last accessed March 10, 2015: http://www.epa.gov/oust/cat/camarchv.htm

The Energy Policy Act of 2005 included a requirement for UST release reports to include a source and cause. A LUSTLine report analyzed 2009 data reports from 47 states reviewing 5,168 UST releases (Eighmey 2011). While the data point to some areas where leaks are common and uncommon, approximately one-third of leaks were listed as other or unknown. Some releases occur no matter what fuel is being delivered or stored. These releases include physical/ mechanical damage (14.9\%), overfills (4.8\%), spills (3.8\%), and installation problems $(1.0 \%)$. Transportation fuels can cause corrosion, and this study found corrosion caused $7.5 \%$ of releases. The topic of STP corrosion comes up as an issue, but a small scoping study performed for RFA found that STPs were not failing. This 2009 report shows the STP as the source of a release in just one of 5,168 incidents. The EPA reviewed 608 UST releases in 2004 and found causes of release were physical/mechanical (39.8\%), other/unknown (27.0\%), spill/overfill (26.6\%), and installation (3.1\%) (EPA 2004). Table 2 summarizes 2009 data for cause and source with detailed data available in Appendix A. 


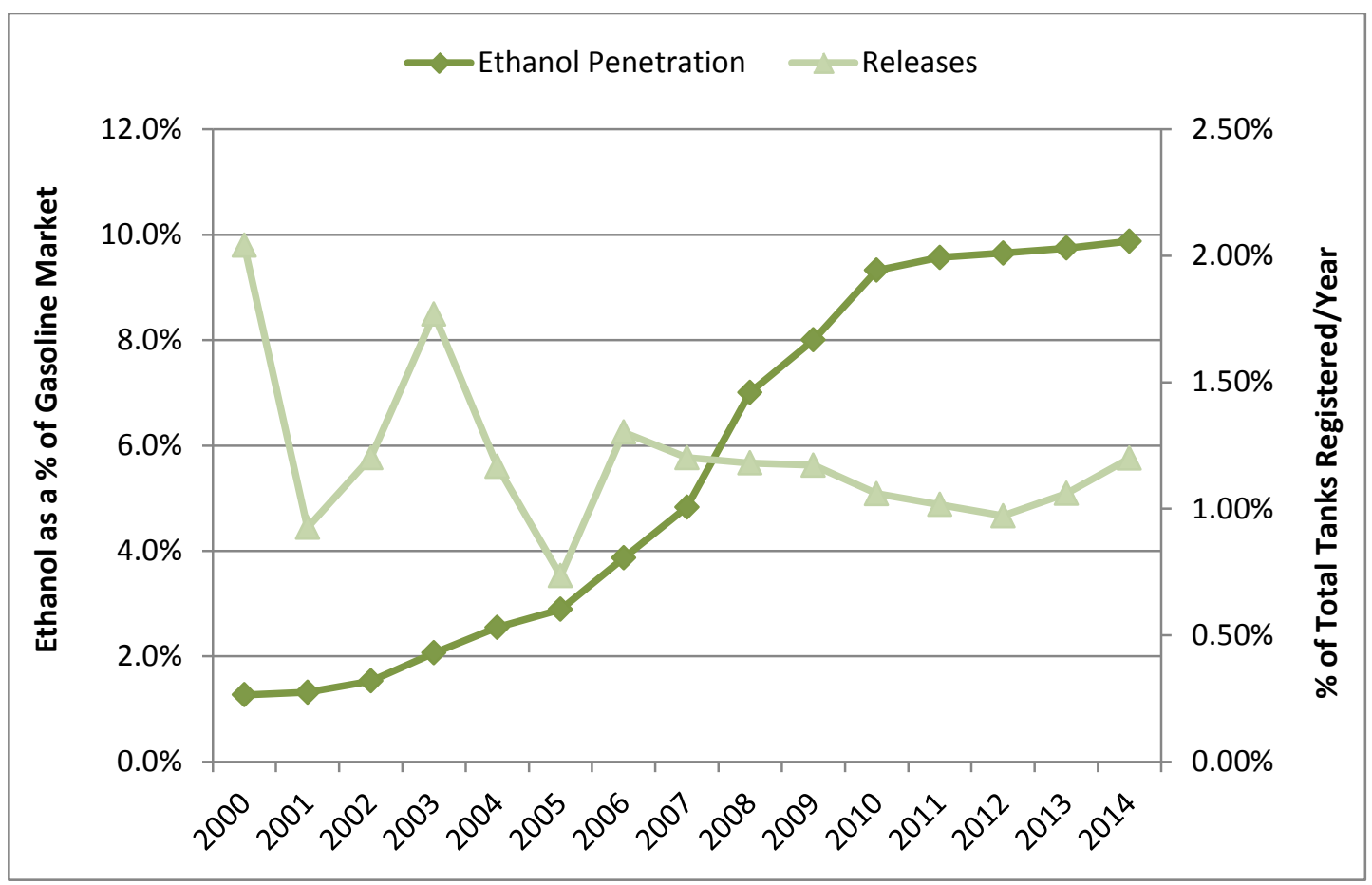

Figure 3. Ethanol penetration and UST releases

Source: Energy Information Agency U.S. Product Supplied of Finished Motor Gasoline:

http://www.eia.gov/tools/faqs/faq.cfm?id=23\&t=10 and Monthly Energy Review Table 10.3 Fuel Ethanol Overview: http://www.eia.gov/totalenergy/data/monthly/

Table 2. Sources and Causes of UST Releases

\begin{tabular}{lrr}
\hline UST Releases & \multicolumn{2}{c}{$\mathbf{2 0 0 9}$ Data } \\
& \multicolumn{2}{c}{ (5,168 releases) } \\
\hline Source & \multicolumn{1}{c}{ \% } \\
\hline Tank & 1,616 & $31.3 \%$ \\
Piping & 720 & $13.9 \%$ \\
Dispenser & 655 & $12.7 \%$ \\
STP & 76 & $1.5 \%$ \\
Delivery Problem & 342 & $6.6 \%$ \\
Other & 564 & $10.9 \%$ \\
Unknown & 1,195 & $23.1 \%$ \\
\hline Physical/Mechanical Damage & 770 & $14.9 \%$ \\
Spill or Overfill & 441 & $8.5 \%$ \\
Corrosion & 385 & $7.4 \%$ \\
Installation & 54 & $1.0 \%$ \\
Other & 466 & $9.0 \%$ \\
Unknown & 3,051 & $59.0 \%$ \\
\hline
\end{tabular}

Source: Eighmey, C., March 2011, LUSTLine Bulletin \#67. Accessed March 10, 2015: http://www.neiwpcc.org/lustline/lustline_pdf/lustline_67.pdf . 
As of January 2003, FDEQ requires County Tanks Program inspectors to submit a leak autopsy form. A 2007 study reviewed Florida leak data and found the sources were spill buckets (48\%), piping (14\%), dispensers (12\%), and tanks (10\%) (Mott-Smith 2007). The causes were unknown $(36 \%)$, overfill $(25 \%)$, mechanical $(16 \%)$, material $(10 \%)$, and corrosion $(7 \%)$. Spill buckets are designed to reduce leaks during fuel delivery. At the time of the report, Florida's E10 penetration was only $5 \%$, so these results do not reflect E10 storage releases but do highlight the importance of maintenance and appropriate fill techniques.

The literature review was directed specifically at identifying ethanol sensitive equipment and included conversations with several leading infrastructure experts to determine if there was evidence and/or literature showing issues with E10 in USTs. Experts suggested that the long, slow introduction of E10 allowed time for refueling equipment manufacturers to adjust to it. None of the experts was aware of any reports and thought it would be unlikely to find any reports on E10 releases. There are examples of equipment failing such as Total Containment, Inc. flexible piping, but it was the opinion of experts that poorly made products would have failed with any fuel, and the failures of flexible piping occurred not long after their introduction and prior to the widespread use of E10. This is not to say that there were no issues during the deployment of E10, just that there were no known releases and no reports on this subject. An Oak Ridge National Laboratory study of E15 stated "UST stakeholders generally consider fueling infrastructure materials designed for use with E0 to be adequate for use with E10, and there are no known instances of major leaks or failures directly attributable to ethanol use. It is conceivable that many compatibility issues, including accelerated corrosion, do arise and are corrected onsite and, therefore do not lead to a release." (Kass et al. 2012).

Several experts cited EPA work on STP corrosion, and both EPA and Battelle work on ultra-low sulfur diesel (ULSD) corrosion. The National Renewable Energy Laboratory (NREL) previously reviewed the STP corrosion issue for RFA. STPs draw fuel from the UST and deliver it to pipes connected to an aboveground dispenser. The State of Tennessee and EPA OUST have investigated and presented on premature STP corrosion. The theory on the cause is that temperature differentials between sumps and UST systems in summer months (or in warm and humid climates) may enable vapors to enter the STP sumps. Vapors that may contain ethanol capable of dissolving in water may condense on metallic portions of an STP, which reacts with acetobacter and oxygen to form acetic acid, leading to corrosion. NREL spoke with numerous state UST offices and county-level experts and did not find any evidence that corrosion was leading to failures or early replacement of STPs. Accelerated corrosion of ULSD UST systems has been observed nationwide. These instances of corrosion started to be reported in 2007 when ULSD was first introduced. The cause of corrosion is currently under investigation, and an EPA OUST study on ULSD corrosion is expected in late 2015. 


\section{Equipment at Station}

A service station consists of many interconnected pieces of refueling equipment necessary to deliver fuel to vehicles. There are approximately 60 pieces of equipment at a station designed to handle fuel and vapor. The equipment delivering fuel to a vehicle includes tanks, pipes, submersible turbine pump, dispenser, and hanging hardware. The remainder and majority of equipment are used to prevent, detect, and contain releases and there is equipment for fuel delivery. This category includes overfill protection, leak detection, shear valves, fill and vapor caps and adaptors, containment sumps and all associated fittings and accessories of these equipment types.

Figure 4 is a diagram of equipment at a station. Table 3 provides a list of the equipment shown in the diagram and includes the purpose of the equipment; common materials; if the equipment is listed by UL, and if it is UL listed, is it tested with fuel or not; if it was tested with fuel; and what the highest level of ethanol listing available under the standard is. Note that \#1 in Figure 4 shows just the tank on the diagram, but the table includes information about steel, fiberglass, and aboveground storage tanks and their protections. This list is comprehensive, and not all stations will have equipment on this list. The table data were taken from the following sources: equipment list and diagram (Source North America); UL; equipment materials (manufacturer product websites and catalogs); and function (PEI Wiki and manufacturer product websites and catalogs).

All known manufacturer website product pages and catalogs were reviewed for every equipment type and model to determine if the products could be used with blends above E10. All known manufacturers were contacted to review compatibility lists. This resulted in an extensive list of equipment compatible with blends above E10. Appendix B provides an equipment list of ULlisted aboveground components for blends above E10. Appendix $\mathrm{C}$ provides a compatibility list of tanks. Appendix D is a list of compatible pipes. Appendix E provides information for other UST equipment with manufacturer, equipment type, model names/numbers, ethanol compatibility (\%), if it is UL listed, and if it is listed for the ethanol fuel determined by the manufacturer. It is important to note that manufacturers typically keep product names over time but may change product model numbers. Also, manufacturers will introduce new product names, and there is a higher likelihood that these products will be compatible with E15.

Determination of compatibility of equipment with ethanol blends is determined by both regulations and manufacturer statements. Manufacturers have laboratories where they conduct fuels testing to determine if the materials they are using work with a range of fuels. Tanks are subject to EPA OUST regulations, and all existing tank manufacturers provided letters stating compatibility with ethanol blends (see Appendix A). Tanks, pipes, and most aboveground equipment are typically UL listed for specific fuels. This includes dispensers, breakaways, hoses, nozzles, swivels, shear valves, and STPs.

Some manufacturers of other UST equipment make an effort to obtain UL listing for all their products, some obtain it for certain products, and others do not obtain UL listing for their products. Many products are approved by the manufacturer for blends above E10 but are not UL listed for blends above E10. This is largely due to the recent availability of ethanol test fluids under UL testing standards, and over time it is expected that more equipment will be UL listed 
for blends above E10. In many instances, there is not a history of many manufacturers obtaining UL listing for certain product types such as fill equipment or containment sumps.

There is no regulation that requires station owners to keep records of their equipment, making determination of compatibility challenging for stations without equipment records. One potential source of tank information is the STI, which maintains a list of steel tanks if owners send in the warranty card. STI also provides a method to determine tank type and manufacturer (see Appendix F). 


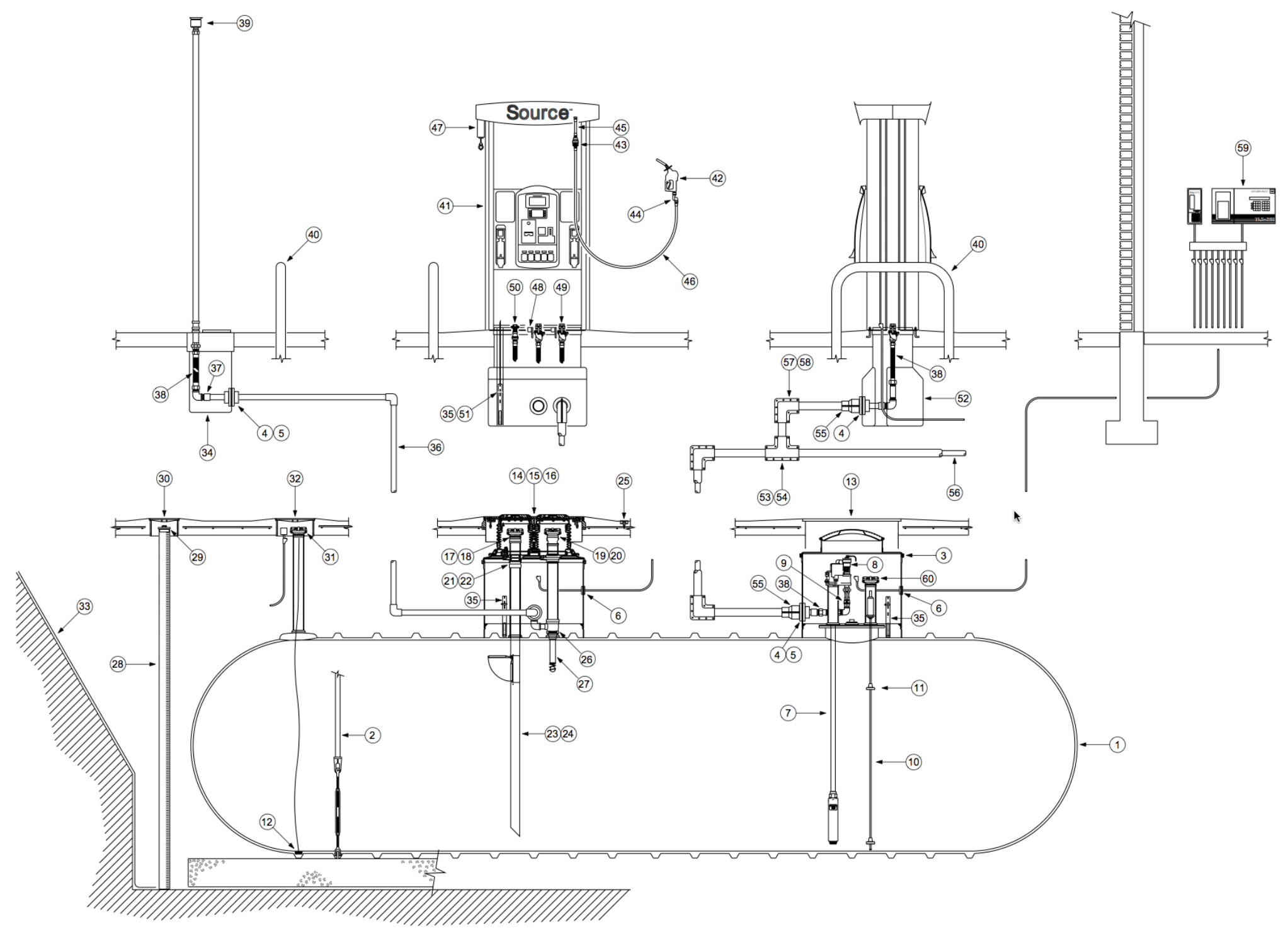

Figure 4. Station equipment diagram 
Table 2. Station Equipment List-Materials and Function

\begin{tabular}{|c|c|c|c|c|c|c|c|}
\hline \# & Equipment & UL & $\begin{array}{l}\text { UL } \\
\text { Std. }\end{array}$ & $\begin{array}{c}\text { Test } \\
\text { wl } \\
\text { fuel }\end{array}$ & $\begin{array}{l}\text { Ethanol Test } \\
\text { fluids }\end{array}$ & Materials & Function \\
\hline 1 & Tank-steel & yes & 58 & no & none & steel & Stores fuel. \\
\hline 1 & Tank-fiberglass & yes & 1316 & yes & E100 & fiberglass & Stores fuel. \\
\hline 1 & $\begin{array}{l}\text { Tank-external corrosion protection } \\
\text { Jacketed steel tank }\end{array}$ & yes & 1746 & yes $^{a}$ & $\mathrm{E} 100^{\mathrm{a}}$ & & Protects tank from corrosion. \\
\hline 1 & Tank-lining and upgrades & yes & 1856 & yes & E100 & & General tank protection. \\
\hline 1 & Tank-above ground & yes & $142 / 142 \mathrm{~A}$ & no & none & fiberglass or steel & Stores fuel. \\
\hline 1 & Tank-above ground fire protection & yes & $2080 / 2085$ & no & none & & Protects tank from fire. \\
\hline 2 & Tank straps & no & & & & $\begin{array}{l}\text { metal, fiberglass, } \\
\text { and other }\end{array}$ & $\begin{array}{l}\text { Outside of tank and usually made of concrete. Devices } \\
\text { installed in storage tank excavations to prevent tanks from } \\
\text { floating out of the ground in event of a high level of } \\
\text { groundwater in the excavation or a high groundwater level } \\
\text { after the installation is complete. }\end{array}$ \\
\hline 3 & Sump and cover (tank) & yes & 2447 & yes & E85 & \begin{tabular}{|l|l}
$\begin{array}{l}\text { polyethylene, } \\
\text { fiberglass }\end{array}$ \\
\end{tabular} & Contains spills from a tank. \\
\hline 4 & Sump entry fitting (boot) & yes & 2447 & yes & E85 & \begin{tabular}{|l|} 
fiberglass, bronze, \\
stainless steel, nitrile \\
rubber
\end{tabular} & $\begin{array}{l}\text { These seals provide a studded flange connection to create a } \\
\text { positive and secure seal where the rubber contacts the } \\
\text { sump wall and also around the pipe or conduit. }\end{array}$ \\
\hline 5 & Sump penetration fittings & yes & 2447 & yes & E85 & $\begin{array}{l}\text { fiberglass or flexible } \\
\text { plastic }\end{array}$ & $\begin{array}{l}\text { A fitting that provides a liquid and vapor-tight seal around } \\
\text { both the piping or conduit and the wall of a containment } \\
\text { sump. }\end{array}$ \\
\hline 6 & Flexible entry boots (conduit entry) & yes & no & no & none & $\begin{array}{l}\text { glass filled nylon, } \\
\text { nitrile }\end{array}$ & Pipe where electric wires are inserted. \\
\hline 7 & Submersible turbine pump & yes & $\begin{array}{ll}428 \\
428 \mathrm{~A} \\
\end{array}$ & yes & $\begin{array}{l}\text { E10 } \\
\text { E25 and/or E85 }\end{array}$ & $\begin{array}{l}\text { cast aluminum, steel, } \\
\text { flurocarbon }\end{array}$ & Delivers fuel from the tank to the dispenser. \\
\hline 8 & Mechanical line leak detector & yes & 1238 & no & none & \begin{tabular}{|l|} 
brass, stainless \\
steel, copper, \\
fluorocarbon
\end{tabular} & $\begin{array}{l}\text { A device used to detect the presence of a leak in the piping. } \\
\text { Usually connected to the STP. }\end{array}$ \\
\hline 9 & Ball valve & yes & $\begin{array}{ll}842 \\
842 A\end{array}$ & yes & $\begin{array}{l}\text { E10 } \\
\text { E25 and/or E85 } \\
\end{array}$ & $\begin{array}{l}\text { brass, plated steal, } \\
\text { vinyl, fluorocarbon }\end{array}$ & A valve in a piping system that allows or stops flow of fuel. \\
\hline 10 & Magnetostrictive probe & yes & 1238 & no & none & $\begin{array}{l}\text { stainless steel, nitrile } \\
\text { rubber }\end{array}$ & $\begin{array}{l}\text { A form of measurement technology used in in-tank electronic } \\
\text { monitoring systems. This is a leak detection method that } \\
\text { relies on sound waves and a magnet. }\end{array}$ \\
\hline 11 & Float kit & yes & 1238 & no & none & \begin{tabular}{|l|} 
nitrile rubber, \\
fluoropolymer
\end{tabular} & $\begin{array}{l}\text { Works in conjunction with the magnetostrictive probe to } \\
\text { determine inventory and identify leaks. }\end{array}$ \\
\hline 12 & Interstitial sensor & yes & 1238 & no & none & & $\begin{array}{l}\text { An electronic device that can detect the presence of water, } \\
\text { liquid product, product vapors or a loss of pressure or } \\
\text { vacuum in the interstice of a tank, a tank top sump, fuel } \\
\text { dispenser sump, or observation well. }\end{array}$ \\
\hline 13 & Manhole-composite & yes & 2447 & yes & E85 & $\begin{array}{l}\text { fiberglass, steel, } \\
\text { resin, nitrile }\end{array}$ & Manhole covering the STP sump. \\
\hline
\end{tabular}




\begin{tabular}{|c|c|c|c|c|c|c|c|}
\hline \# & Equipment & UL & $\begin{array}{l}\text { UL } \\
\text { Std. }\end{array}$ & $\begin{array}{c}\text { Test } \\
\text { wl } \\
\text { fuel }\end{array}$ & $\begin{array}{l}\text { Ethanol Test } \\
\text { fluids }\end{array}$ & Materials & Function \\
\hline 14 & $\begin{array}{l}\text { Manhole-multi-port spill } \\
\text { containment }\end{array}$ & no & & & & $\begin{array}{l}\text { fiberglass, steel, } \\
\text { aluminum, iron, } \\
\text { polyethelene, resin, } \\
\text { nitrile }\end{array}$ & $\begin{array}{l}\text { Provides spill containment for UST fill pipes and vapor } \\
\text { recovery risers. They are installed on top of the tank sump. }\end{array}$ \\
\hline 15 & Spill bucket & yes & 2447 & yes & E85 & $\begin{array}{l}\text { cast aluminum, cast } \\
\text { iron, polyethylene, } \\
\text { stainless steel, nitrile }\end{array}$ & $\begin{array}{l}\text { Prevents spilled product from entering the soil near the fill } \\
\text { and vapor return riser connections on underground storage } \\
\text { tanks during normal tank filling operation, or if the tank } \\
\text { overfilled. }\end{array}$ \\
\hline 16 & Fuel grade ID tag & yes & 969 & no & none & & Identifies fuel being stored. \\
\hline 17 & Fill adaptor (top or side) & yes & 2583 & yes & E85 & $\begin{array}{l}\text { Bronze, nylon, } \\
\text { stainless steel, nitrile } \\
\text { rubber, fluorocarbon }\end{array}$ & $\begin{array}{l}\text { A permanent fitting at the top of the fill pipe of an } \\
\text { underground storage tank that allows for a delivery hose to } \\
\text { be quickly connected to the fill pipe in a liquid tight manner. }\end{array}$ \\
\hline 18 & Fill cap (top or side) & yes & 2583 & yes & E85 & $\begin{array}{l}\text { brass, epoxy coated } \\
\text { aluminum }\end{array}$ & A cap that fits over the open end of a fill pipe. \\
\hline 19 & Vapor adaptor & yes & 2583 & yes & E85 & $\begin{array}{l}\text { bronze, conductive } \\
\text { nylon, stainless } \\
\text { steel, nitrile }\end{array}$ & $\begin{array}{l}\text { A special fitting in a Stage I vapor recovery system that is } \\
\text { installed at the top of the vapor recovery riser in two-point } \\
\text { and manifolded Stage I vapor recovery systems. The vapor } \\
\text { recovery adaptor mates to the vapor recovery elbow } \\
\text { attached by the fuel delivery driver prior to a delivery. }\end{array}$ \\
\hline 20 & Vapor cap & yes & 2583 & yes & E85 & $\begin{array}{l}\text { aluminum, glass } \\
\text { filled nylon, iron, } \\
\text { copper, stainless } \\
\text { steel, nitrile }\end{array}$ & A dust cover for the vapor recovery system. \\
\hline 21 & $\begin{array}{l}\text { Face seal adaptor (threaded riser } \\
\text { adaptor) }\end{array}$ & yes & 2583 & yes & E85 & aluminum & $\begin{array}{l}\text { Connects fill pipe to swivel fill adaptor and Provides a flat, } \\
\text { true sealing surface on threaded fill pipe where a gasket } \\
\text { seal exists. is installed on the fill pipe riser below the spill } \\
\text { container to provide a true sealing surface for the drop tube } \\
\text { flange on the overfill prevention valves. }\end{array}$ \\
\hline 22 & Jack screw kit & yes & 2583 & yes & E85 & steel & $\begin{array}{l}\text { The jack screw is designed to lock an overfill valve or a drop } \\
\text { tube into an a spill container base below the outlet of the } \\
\text { drain valve. }\end{array}$ \\
\hline 23 & Overfill prevention valve & yes & 2583 & yes & E85 & $\begin{array}{l}\text { cast aluminum, nitrile } \\
\text { rubber, fluoro based } \\
\text { seals, acetal, } \\
\text { stainless steel, } \\
\text { acetal, closed cell } \\
\text { foam }\end{array}$ & $\begin{array}{l}\text { Prevents the overfill of underground storage tanks by } \\
\text { providing a positive shut-off of product delivery. }\end{array}$ \\
\hline 24 & Drop tube (often a part of \#23) & yes & 2583 & yes & E85 & stainless steel & $\begin{array}{l}\text { Delivers fuel from fill cap to bottom of tank resultig in less } \\
\text { vapors. }\end{array}$ \\
\hline 25 & Fuel grade ID \# & yes & 969 & no & none & & Identifies fuel type. \\
\hline
\end{tabular}




\begin{tabular}{|c|c|c|c|c|c|c|c|}
\hline \# & Equipment & UL & $\begin{array}{l}\text { UL } \\
\text { Std. }\end{array}$ & $\begin{array}{c}\text { Test } \\
\text { wl } \\
\text { fuel }\end{array}$ & $\begin{array}{l}\text { Ethanol Test } \\
\text { fluids }\end{array}$ & Materials & Function \\
\hline 26 & Extractor tee & yes & 2583 & yes & E85 & cast iron, zinc & $\begin{array}{l}\text { A fitting that allows access to ball valve be removed or } \\
\text { repaired without the necessity of breaking concrete, digging } \\
\text { down to the component, or cutting a hole in the tank. }\end{array}$ \\
\hline 28 & $\begin{array}{l}\text { Ball float vent valve (flow } \\
\text { restriction device FRD) }\end{array}$ & yes & 2583 & yes & E85 & $\begin{array}{l}\text { Brass, chrome, } \\
\text { fluoro based seals }\end{array}$ & $\begin{array}{l}\text { During a product delivery, as the tank level rises, a } \\
\text { counterweight stainless steel ball seats on the valve body } \\
\text { and restricts flow of vapors back to the transport truck. }\end{array}$ \\
\hline 27 & Monitoring well screen (pipe) & no & no & no & none & $\begin{array}{l}\text { plastic, } \\
\text { polypropylene (filter } \\
\text { wrapping the pipe) }\end{array}$ & $\begin{array}{l}\text { A slotted or screened tube or pipe, positioned vertically in an } \\
\text { underground tank excavation, that permits an operator to } \\
\text { check conditions in the excavation and, in particular, to } \\
\text { determine whether there may be a leak in the tank system. }\end{array}$ \\
\hline 29 & Well cap-monitoring & yes & 2583 & yes & E85 & plastic, nitrile rubber & Provides access to well screen. \\
\hline 30 & Manhole-monitoring & no & & & & cast iron & $\begin{array}{l}\text { Any tank opening, including those where delivery and vapor } \\
\text { return hoses are connected. }\end{array}$ \\
\hline 31 & Interstitial cap & yes & 2583 & yes & E85 & & $\begin{array}{l}\text { Interstitial Caps are installed on tank riser pipes to help } \\
\text { prevent vapors from escaping or water from entering the } \\
\text { tank }\end{array}$ \\
\hline 32 & Manhole & no & & & & $\begin{array}{l}\text { fiberglass, steel, } \\
\text { resin, nitrile }\end{array}$ & Access to UST system. \\
\hline 33 & Roll filter fabric & no & & & & $\begin{array}{l}\text { polypropylene, or } \\
\text { polyester }\end{array}$ & $\begin{array}{l}\text { A porous synthetic fabric, used in underground storage tank } \\
\text { excavations, to provide a barrier between different types of } \\
\text { soil, or between backfill and adjacent soil. }\end{array}$ \\
\hline 34 & Transition sump-vent & yes & 2447 & yes & E85 & $\begin{array}{l}\text { polyethylene, } \\
\text { fiberglass }\end{array}$ & $\begin{array}{l}\text { A liquid tight container typically installed at a point where } \\
\text { product piping from an aboveground storage tank transitions } \\
\text { to underground piping. Other forms of transition sumps may } \\
\text { accomodate piping from an UST tank to AST generators, or } \\
\text { for piping that resides only below grade. The transition sump } \\
\text { exists to contain any contaminants that may leak from any } \\
\text { piping or their connectors and to isolate and protect metallic } \\
\text { components or equipment from the elements. }\end{array}$ \\
\hline 35 & Sump sensor & yes & 1238 & no & none & & $\begin{array}{l}\text { An electronic device that can detect the presence of water, } \\
\text { liquid product, product vapors or a loss of pressure or } \\
\text { vacuum in the interstice of a tank, a tank top sump, fuel } \\
\text { dispenser sump, or observation well. }\end{array}$ \\
\hline 36 & Pipe & yes & 971 & yes & E100 & $\begin{array}{l}\text { fiberglass or flexible } \\
\text { plastic }\end{array}$ & $\begin{array}{l}\text { Delivers fuel between different pieces of equipment in the } \\
\text { refueling system. }\end{array}$ \\
\hline 37 & Pipe adaptor & yes & 971 & yes & E100 & $\begin{array}{l}\text { aluminum, stainless } \\
\text { steel, nitrile rubber } \\
\text { or fluoro based } \\
\text { elastomers }\end{array}$ & $\begin{array}{l}\text { connect fuel delivery transport truck hoses or nozzles to the } \\
\text { fill pipe of an aboveground storage tank }\end{array}$ \\
\hline 38 & Flexible connector & yes & 2039 & yes & E85 & $\begin{array}{l}\text { stainless steel, } \\
\text { fluoro based } \\
\text { elastomers or nitrile } \\
\text { rubber }\end{array}$ & $\begin{array}{l}\text { Flexible Connectors can be used as a convenient means of } \\
\text { connecting piping to pumps and dispensers and throughout } \\
\text { the piping systems where connections and changes of } \\
\text { direction are necessary. }\end{array}$ \\
\hline
\end{tabular}




\begin{tabular}{|c|c|c|c|c|c|c|c|}
\hline \# & Equipment & UL & $\begin{array}{l}\text { UL } \\
\text { Std. }\end{array}$ & $\begin{array}{c}\text { Test } \\
\text { wl } \\
\text { fuel }\end{array}$ & $\begin{array}{l}\text { Ethanol Test } \\
\text { fluids }\end{array}$ & Materials & Function \\
\hline 39 & Vent & yes & 2853 & yes & E85 & aluminum, brass & $\begin{array}{l}\text { A pipe, usually } 2 \text { inches in diameter, that extends from a } \\
\text { gasoline storage tank at a service station to a point } 12 \text { feet } \\
\text { or more above grade level. The vent allows vapors that build } \\
\text { up in the tank to escape and outside air to enter, thus } \\
\text { keeping the tank at atmospheric pressure when liquids are } \\
\text { added or removed. }\end{array}$ \\
\hline 40 & Steel bumper & no & & & & steel & $\begin{array}{l}\text { Not fuel wetted. Designed to protect dispenser from vehicle } \\
\text { impact. }\end{array}$ \\
\hline 41 & Dispenser & yes & $\begin{array}{l}87 \\
87 \mathrm{~A}\end{array}$ & yes & $\begin{array}{l}\text { E10 } \\
\text { E25 and/or E85 }\end{array}$ & \begin{tabular}{|l|} 
multiple \\
parts/materials \\
(metal, plastic, \\
elastomers) in a \\
dispenser-treated as \\
a whole piece of \\
equipment
\end{tabular} & $\begin{array}{l}\text { The dispenser delivers fuel from the piping connected to the } \\
\text { STP through the hanging hardware into a vehicle. It has } \\
\text { numerous parts including meters, valves, seals, and } \\
\text { electronics. }\end{array}$ \\
\hline 42 & Nozzle & yes & $\begin{array}{l}2586 \\
2586 A\end{array}$ & yes & $\begin{array}{l}\text { E10 } \\
\text { E25 and/or E85 }\end{array}$ & $\begin{array}{l}\text { aluminum, plastic, } \\
\text { fluorocarbon }\end{array}$ & $\begin{array}{l}\text { A device consisting of a spout, handle and operating lever, } \\
\text { attached to the end of a hose and used for controlling the } \\
\text { flow of a liquid motor fuel. }\end{array}$ \\
\hline 43 & Breakaway & yes & $\begin{array}{l}567 \\
567 A\end{array}$ & yes & $\begin{array}{l}\text { E10 } \\
\text { E25 and/or E85 }\end{array}$ & $\begin{array}{l}\text { steel, zinc, nylon, } \\
\text { acetal, fluorocarbon }\end{array}$ & $\begin{array}{l}\text { A device that disconnects dispenser from hanging hardware } \\
\text { if a vehicle pulls away with the nozzle still in the vehicle gas } \\
\text { tank. }\end{array}$ \\
\hline 44 & Swivel & yes & \begin{tabular}{|l|}
567 \\
$567 A$ \\
\end{tabular} & yes & $\begin{array}{l}\text { E10 } \\
\text { E25 and/or E85 } \\
\end{array}$ & \begin{tabular}{|l|} 
aluminum, zinc, \\
nitrile rubber
\end{tabular} & $\begin{array}{l}\text { The swivel permits the nozzle to be rotated without rotating } \\
\text { the hose at the same time. }\end{array}$ \\
\hline 45 & Whip hose & yes & $\begin{array}{l}330 \\
330 A\end{array}$ & yes & $\begin{array}{l}\text { E10 } \\
\text { E25 and/or E85 }\end{array}$ & nitrile rubber & $\begin{array}{l}\text { A short length of hose with threaded fittings at both ends } \\
\text { that is usually installed adjacent to a breakaway valve. The } \\
\text { whip hose ensures that forces exerted during a drive off are } \\
\text { aligned with the axis of a breakaway valve. }\end{array}$ \\
\hline 46 & Hose & yes & $\begin{array}{l}330 \\
330 \mathrm{~A} \\
\end{array}$ & yes & $\begin{array}{l}\text { E10 } \\
\text { E25 and/or E85 }\end{array}$ & nitrile rubber & Delivers fuel to the nozzle. \\
\hline 47 & Hose retractor & no & & & & aluminum, polyester & $\begin{array}{l}\text { A cable device, fixed to a gasoline station hose and } \\
\text { dispenser, to pull the hose back to its storage position after } \\
\text { it has been used. Usually used for longer hoses that allow } \\
\text { refueling on either side of a vehicle. }\end{array}$ \\
\hline 48 & Stablizer bar kit & yes & 2447 & yes & E85 & steel & $\begin{array}{l}\text { Provides support in a dispenser sump to attach the shear } \\
\text { valve. }\end{array}$ \\
\hline 49 & Shear valve & yes & $\begin{array}{l}842 \\
842 \mathrm{~A}\end{array}$ & yes & $\begin{array}{l}\text { E10 } \\
\text { E25 and/or E85 } \\
\end{array}$ & $\begin{array}{l}\text { cast iron, stainless } \\
\text { steel, fluorocarbon }\end{array}$ & $\begin{array}{l}\text { Cuts off the flow of fuel from the UST system in the event of } \\
\text { vehicle impact, fire, or other catastrophe. }\end{array}$ \\
\hline 50 & Shear valve-vapor (stage II only) & yes & $\begin{array}{l}842 \\
842 A\end{array}$ & yes & $\begin{array}{l}\text { E10 } \\
\text { E25 and/or E85 }\end{array}$ & $\begin{array}{l}\text { cast iron, stainless } \\
\text { steel, fluorocarbon }\end{array}$ & $\begin{array}{l}\text { A fitting installed in the vapor piping at the base of a } \\
\text { dispenser that is designed to "shear" or break off if the } \\
\text { dispenser cabinet is dislodged from its base. }\end{array}$ \\
\hline
\end{tabular}




\begin{tabular}{|c|c|c|c|c|c|c|c|}
\hline \# & Equipment & UL & $\begin{array}{l}\text { UL } \\
\text { Std. }\end{array}$ & \begin{tabular}{|c|} 
Test \\
wl \\
fuel
\end{tabular} & $\begin{array}{l}\text { Ethanol Test } \\
\text { fluids }\end{array}$ & Materials & Function \\
\hline 51 & Sensor tube & yes & 1238 & no & none & & Contains the sump sensor. \\
\hline 52 & Dispenser sump & yes & 2447 & yes & E85 & $\begin{array}{l}\text { fiberglass, flexible } \\
\text { plastic }\end{array}$ & A container designed to contain leaks from dispensers \\
\hline 53 & Pipe-secondary containment tee & yes & 971 & yes & E100 & $\begin{array}{l}\text { flexible plastic, } \\
\text { fiberglass }\end{array}$ & A pipe fitting connector \\
\hline 54 & Pipe-product tee & yes & 971 & yes & E100 & $\begin{array}{l}\text { flexible plastic, } \\
\text { fiberglass }\end{array}$ & A pipe fitting connector \\
\hline 55 & Concentric reducer & yes & 2447 & yes & E85 & & $\begin{array}{l}\text { A seal that connects the sump entry/termination fitting to } \\
\text { secondary containment pipe. }\end{array}$ \\
\hline 56 & Pipe-product & yes & 971 & yes & E100 & $\begin{array}{l}\text { flexible plastic, } \\
\text { fiberglass }\end{array}$ & Delivers fuel between tank and dispenser. \\
\hline 57 & $\begin{array}{l}\text { Pipe-secondary containment } \\
\text { elbow }\end{array}$ & yes & 971 & yes & E100 & $\begin{array}{l}\text { flexible plastic, } \\
\text { fiberglass }\end{array}$ & A pipe fitting that makes a right-angle turn \\
\hline 58 & Pipe-product elbow & yes & 971 & yes & E100 & $\begin{array}{l}\text { flexible plastic, } \\
\text { fiberglass }\end{array}$ & A pipe fitting that makes a right-angle turn \\
\hline 40 & Steel bumper & no & & & & steel & Protects equipment from vehicle impact. \\
\hline 59 & Console & yes & 1238 & no & none & & $\begin{array}{l}\text { A control unit, containing switches, keys, or similar elements, } \\
\text { used to control the operation of a dispenser or other device } \\
\text { at a gasoline dispensing facility. }\end{array}$ \\
\hline 60 & Probe cap adaptor & yes & 2583 & yes & E85 & $\begin{array}{l}\text { cast aluminum, nitrile } \\
\text { rubber }\end{array}$ & $\begin{array}{l}\text { Monitoring Probe Caps are installed on tank riser pipes to } \\
\text { help prevent vapors from escaping or water from entering } \\
\text { the tank. Monitoring Probe Caps include a wire grommet } \\
\text { fitting to accommodate the electronic tank gauge probe. }\end{array}$ \\
\hline
\end{tabular}




\subsection{Dispensers, Hanging Hardware, Shear Valves, and STPs}

There are multiple dispenser options to sell E15: retrofit an existing dispenser with a UL-listed kit, purchase a UL-listed E25 dispenser (minimal cost over conventional E10 dispenser), or purchase a UL-listed E85 blender pump dispenser (higher cost but more options for fuel offerings). Both Gilbarco and Wayne provide UL-listed dispensers for blends above E10. Credit card companies are requiring retail fueling stations to update their dispensers to accept new chip and PIN secure credit cards by October 2017, at which time fraud liability would switch to station owners if they have not updated their equipment. This presents an opportunity to increase E25 UL-listed equipment through either a retrofit kit if electronics are being upgraded to accommodate the new credit cards, or if a station must purchase a new dispenser, they could pay a minimal amount more for an E25 dispenser.

Hanging hardware includes hoses, nozzles, breakaways, and swivels (Figure 5). OPW obtained E25 listing for a conventional swivel and breakaway, for which there is no price premium. Husky offers UL-listed E25 and E85 nozzles while OPW offers a UL-listed E85 nozzle. EMCO Wheaton, IRPCO, and Veyance have hoses warrantied for E15, and Veyance has a UL-listed E85 hose product. A best practice is to replace all hanging hardware with E15-compatible equipment.

Shear valves are an important piece of safety equipment that cut off the flow of fuel from the UST to the dispenser to prevent a release in the event of an accident dislodging the dispenser or fire. UL-listed E85 shear valves are available from Franklin Fueling and OPW.

STPs draw fuel from the tank and into piping that delivers the fuel to the dispenser. Both VeederRoot and Franklin Fueling offer UL-listed E85 pumps.

Appendix B lists specific manufacturers and models for use with blends above E10.

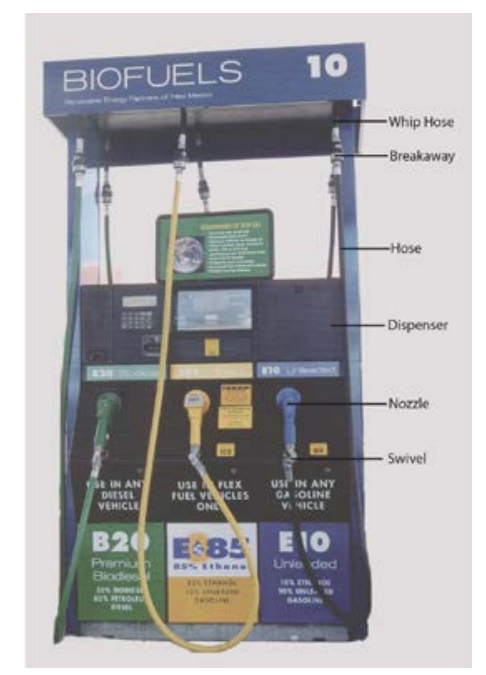

Figure 5. Aboveground equipment

(NREL 13531) 


\subsection{Tanks, Pipes, and Other UST Equipment}

\subsubsection{Compatibility of Tanks}

Most tanks are compatible with ethanol blends above E10. Appendix B lists tank manufacturers and their compatibility with ethanol blends. If a station owner does not have equipment lists, the information in Appendix F describes methods to determine tank type.

All existing steel tank companies manufacturing tanks to store transportation fuels have issued signed letters stating compatibility with up to E100 per EPA OUST biofuels guidance. Tanks are listed under UL 58, which does not expose tanks to test fluids. All STI members who fabricate regulated fuel USTs in the United States have UL 58 listings. STI conducted independent testing and determined that steel tanks are compatible with all ethanol blends.

Xerxes and Containment Solutions manufacture fiberglass tanks, and both have E100 listing for their products under UL 1316. ${ }^{11}$ Per EPA OUST's biofuels guidance, Containment Solutions issued a letter stating that all tanks it has manufactured are compatible all ethanol blends. Xerxes and Owens Corning (which no longer manufactures tank) have stated that compatibility depends on tank type and the year manufactured. Appendix $\mathrm{C}$ includes specific information on fiberglass tank compatibility.

The following is from a Fiberglass Tank and Pipe Institute paper on ethanol compatibility (Curran 2015):

"By 1990, Institute member fiberglass tank manufacturers had modified their tanks constructions to handle gasoline with any level of ethanol or methanol up to $100 \%$ for all double-wall fiberglass tanks and in some cases single-wall fiberglass tanks. In 1992, Owens Corning, the manufacturer of the oldest UL Listed fiberglass tanks for petroleum service, advised certain major oil companies that some tanks were approaching 30 years in age and their 30-year warranties would expire. As a result, the affected companies conducted surveys of these older tanks, including tanks in E-10 ethanol service (e.g., in the Midwest) and confirmed that the tanks were performing satisfactorily for continued service. In summary, technical evaluations and historical experience demonstrated that there is no material or technical reason why properly installed pre-1988 piping and tanks in conventional gasoline or MTBE service should not perform equally as well when handling 10 percent ethanol blends."

\subsubsection{Compatibility of Pipes}

Installed pipes are evenly split between fiberglass and flexible plastic pipes. Piping is listed under UL 971. E100 became an eligible test fluid in 1988, and all existing pipe companies have E100 listing (Appendix D). Fiberglass was the primary pipe type for decades. NOV is the only existing company providing fiberglass piping in this market, and its products received E100 listing in 1990. NOV provides a 30-year warranty.

Flexible pipes entered the marketplace in the 1990s after EPA OUST recommended development of jointless pipes. There were some issues with initial deployment and failures of Total Containment piping. Total Containment is no longer in business, and its piping is largely

\footnotetext{
${ }^{11}$ Decades-old fiberglass tanks may only be approved for use with E10; please refer to Appendix C.
} 
believed to have been replaced. This occurred before E10 was widely available. Over time, more robust products were developed, and all existing flexible plastic pipe manufacturers have UL listing for E100. These manufacturers include Advantage Earth Products, Brugg Pipesystems, ${ }^{12}$ Franklin Fueling, NUPI, Omega Flex, and OPW. Both Franklin Fueling and Omega Flex require the use of stainless steel pipe fittings for blends above E10. A typical warranty for flexible pipes is 10 years.

It is likely that there are stations using piping from companies no longer in business, and the compatibility with ethanol blends for these products is unknown.

\subsubsection{Other UST Equipment}

Other associated UST equipment includes sumps and accessories, manholes, flexible connectors, fill caps and adaptors, entry fittings, overfill prevention, leak detection, sensors, drop tubes, vents, and similar. Per EPA OUST's biofuels guidance, several manufacturers have issued letters for specific products and model numbers stating compatibility with various ethanol blends above E10. Some major manufacturers have not issued letters but have provided statements on their website product pages that the products are compatible with various ethanol blends, including E15, E85, and E100. Most manufacturers have their own laboratories where they test their products with fuels. Some smaller manufacturers likely rely on materials analysis to determine compatibility. Appendix D provides a list by manufacturer of compatible equipment.

While UL now has listing standards for most of this equipment, few products have UL listing for E10 and even fewer for blends above E10. This does not mean that the products are not compatible, just that manufacturers have yet to obtain listings.

Retailers should specifically investigate if their leak detection equipment is compatible with E15 (refer to Appendix E). Leak detection equipment is required by federal regulations developed by EPA OUST (EPA 2015b). All federally regulated UST systems (tanks and piping) storing motor fuel must have leak detection equipment to detect any potential releases so the spread of contamination can be stopped before significant environmental impact occurs. Regulations allow for several types of leak detection methods. The National Work Group on Leak Detection Evaluations has developed test protocols for various technologies with blends above E10 (NWGLDE 2011). It is expected that some will function with ethanol blends while others may require testing to determine functionality.

In 2011, Battelle conducted a test of ethanol-blended fuels and an automatic tank gauging system to determine water detection functionality (Carvitti and Gregg 2010). E0 was used as a baseline, and E15 and E85 were tested. Fuel was tested at two tank levels - $25 \%$ and $65 \%$ full. Two methods of water ingress were used: a continuous stream of water into a tank, and a quick water dump followed by a fuel dump. An automatic tank gauging system has a float that performs two functions: product level monitoring that leads directly to leak detection; and water detection. The water detection function detected the water stream with E0 and E15 but was not conclusive for E85.

\footnotetext{
${ }^{12}$ Brugg Pipesystems manufacturers stainless steel pipes, which are rarely used at United States stations.
} 
As a result of the E15 waiver request, the American Petroleum Institute funded a study to determine compatibility of some associated UST equipment, specifically tank vapor recovery equipment and overfill protection devices with E15 (Ken Wilcox Associates 2011). The testing protocol was to expose equipment to test fluids E10 (control) and aggressive E17 (test fluid formula from UL) for four weeks at $140^{\circ} \mathrm{F}$ followed by performance testing. The following equipment was tested: ball float vent valve, monitoring probe cap, overfill prevention valve, replacement drain valve kit (used to drain spill container after an overfill during delivery), swivel product adaptor, and swivel vapor adaptor. The report states that most of the equipment performed well during testing. All ball float vent valves, monitoring probe caps, and replacement drain valve kits passed. Two of three overfill prevention valves passed; the failing product was stuck in the OFF position during performance testing. Swivel product adaptor results were mixed, with one product failing on E10 and passing on aggressive E17 while the other product failed on both fuels. Swivel vapor adaptors did not perform well either with one failing on both test fluids and a second product failing on the E17 test fluid. The adaptor failures happened during performance testing due to leaks in sealing materials. Most manufacturers have upgraded sealing materials in the past few years after this test was performed to address the introduction of more ethanol and ULSD into the market.

The subject of older pipe dopes/sealants and their compatibility with ethanol fuels came up in the course of the original E15 infrastructure work performed by U.S. Department of Energy national laboratories. Pipe dope, also referred to as pipe thread sealant, is a sealing product used to make pipe thread joints leak proof and pressure tight. Refueling equipment with threaded ends is designed to achieve a tight fit during proper assembly but it is a regular practice to use pipe dope in some instances. Appendix $\mathrm{G}$ is a diagram of where pipe dope might be used in a refueling system. Jobbers who install, fix, and replace equipment at stations always have a jar of pipe dope available for use and the two main brands are RectorSeal and Gasoila. Gasoila's pipe thread sealants have used the same formula for decades and are compatible with ethanol blends up to $20 \%{ }^{13}$ RectorSeal No.5 is their best selling product for use at refueling station and the manufacturer said it has long been compatible with ethanol blends including E15. ${ }^{14}$

\footnotetext{
${ }^{13}$ Gasoila pipe thread sealants are compatible with up to $20 \%$ ethanol. Blends above E20 need to use their Gasoila E-Seal product. http://www.gasoila.com/products/pipe-thread-sealants.html

${ }^{14}$ RectorSeal's Pipe Thread Sealant Chart shows No.5 as compatible with gasohol (10\%), however, NREL spoke with their technical staff who said it is compatible with E15.
} 


\section{Conclusions}

This study found that significant changes to safety testing standards have incorporated fuel blends with more than $10 \%$ volume ethanol. This has led to many refueling equipment products compatible with E15. A station owner can compare its equipment records against the compatibility list in the appendices of this report to determine if there is a need to update or upgrade any equipment to sell E15. The majority of tanks are compatible as existing pipe manufacturers have had listing for E100 for many years, UL-listed E25 dispensers and retrofit kits are available, as is hanging hardware (a combination of E25 and E85 UL-listed equipment). Many manufacturers' models, as well as other UST equipment including fill equipment, leak detection, overfill prevention, and containment, are compatible with E15.

A literature review was conducted to determine if there were any negative impacts during the multi-year deployment of E10 nationwide. No incidents of E10 causing releases were identified, and no infrastructure industry experts suggested that there were widespread issues with E10. 


\section{References}

AFDC. (2015). "Public Retail Stations by Year." Alternative Fuels Data Center. Accessed March 15, 2015: http://www.afdc.energy.gov/data/search?q=stations\#10333 .

CARB. (2015). Vapor Recovery Program. California Air Resources Board. Accessed March 24, 2015: http://www.arb.ca.gov/vapor/vapor.htm

Carvitti, J.; Gregg, A. (2010). "Current Status of Leak Detection System Evaluations under EPA's Environmental Technology Verification Program Advanced Monitoring System Center." Presented at the National Tank Conference, September 21, 2010.

Curran, S. "Ethanol Compatibility with Fiberglass UST Systems." Fiberglass Tank and Pipe Institute: Houston, TX. January 2015. Accessed March 23, 2015:

http://www.fiberglasstankandpipe.com/white-papers/general/ethanol-compatibility-withfiberglass-ust-systems/

Eighmey, C. "Come on, Really...Can't We Do Better with the Sources and Causes of Releases?" LUSTLine Bulletin \#67. March 2011, pp 6-7. Accessed March 10, 2015: http://www.neiwpcc.org/lustline/lustline pdf/lustline_67.pdf

EPA. (2004). Evaluation of Releases from New and Upgraded Underground Storage Systems. U.S. Environmental Protection Agency Office of Underground Storage Tanks. Peer Review Draft. August 2004.

EPA. (2011). “Guidance - Compatibility of UST Systems with Biofuel Blends.” U.S. Environmental Protection Agency Office of Underground Storage Tanks. Accessed March 1, 2015: http://www.epa.gov/oust/altfuels/biofuelsguidance.htm.

EPA. (2015a). “UST Performance Measures.” U.S. Environmental Protection Agency Office of Underground Storage Tanks. Accessed March 1, 2015

http://www.epa.gov/oust/cat/camarchv.htm

EPA. (2015b). Detecting UST Releases. U.S. Environmental Protection Agency Office of Underground Storage Tanks. Accessed March 23, 2015:

http://www.epa.gov/oust/ustsystm/leakdet.htm

FDEQ. (2015). Approved Storage Tank Equipment. Florida Department of Environmental Quality. Last accessed March 24, 2015:

http://www.dep.state.fl.us/waste/categories/tanks/pages/equip.htm

Kass, M.; Theiss, T.; Janke, C.; Pawel, S. (2012). Compatibility Study for Plastic, Elastomeric, and Metallic Fueling Infrastructure Materials Exposed to Aggressive Formulations of Ethanolblended Gasoline. ORNL/TM-2012/88. Oak Ridge National Laboratory: Oak Ridge, TN. Accessed November 10, 2014: http://info.ornl.gov/sites/publications/files/pub35074.pdf 
Ken Wilcox Associates. (2011). "Testing of the Functionality of Stage I Vapor Recovery and Overfill Prevention Components." Prepared for American Petroleum Institute by Ken Wilcox Associates, Inc. September 2011.

McCormick, R., Yanowitz, J., Ratcliff, M., Zigler, B. "Review and Evaluation of Studies on the Use of E15 in Light-Duty Vehicles." Prepared by the National Renewable Energy Laboratory for the Renewable Fuels Association. October 2013. Accessed April 6, 2015:

http://ethanolrfa.org/page/-/rfa-association-

site/studies/RFA\%20NREL\%20Review\%20and\%20Evaluation\%20of\%20E15\%20Studies.pdf?n $\underline{\operatorname{ocdn}=1}$

Mott-Smith, M. "Florida's Leak Autopsy Study for Storage Tank Systems: An Enlightening Work in Progress." LUSTLine Bulletin \#56. August 2007, pp. 6-7. Accessed March 25, 2015: http://nepis.epa.gov/Exe/ZyPDF.cgi/60000GPR.PDF?Dockey=60000GPR.PDF

NACS. (2014a). U.S. Convenience Store Count. National Association of Convenience Store Owners. Accessed March 25, 2014:

http://www.nacsonline.com/Research/FactSheets/ScopeofIndustry/Pages/IndustryStoreCount.aspx

NACS. (2014b). 2014 Retail Fuels Report. February 2014. Last accessed March 10, 2015: http://www.nacsonline.com/YourBusiness/FuelsReports/2014/Pages/default.aspx

NACS. (2015). 2015 Retail Fuels Report. February 2015. Last accessed March 10, 2015: http://www.nacsonline.com/YourBusiness/FuelsReports/2015/Documents/2015-NACS-Fuels$\underline{\text { Report full.pdf }}$

NWGLDE. (2011). Acceptable Protocols. National Work Group on Leak Detection Evaluations. Accessed March 25, 2015: http://www.nwglde.org/protocols.html 


\section{Appendix A. EPA OUST Release Data}

2009 release data from 47 states:

\begin{tabular}{|c|c|c|c|c|c|c|c|c|c|c|c|c|c|c|c|c|}
\hline \multicolumn{17}{|c|}{ Cause } \\
\hline \multirow[t]{2}{*}{ Source } & \multicolumn{2}{|c|}{ Total } & \multicolumn{2}{|c|}{ Spill } & \multicolumn{2}{|c|}{ Overfill } & \multicolumn{2}{|c|}{ Phys/Mech Damag } & \multicolumn{2}{|c|}{ Corrosion } & \multicolumn{2}{|c|}{ Install Problem } & \multicolumn{2}{|c|}{ Other } & \multicolumn{2}{|c|}{ Unknown } \\
\hline & \# & $\%$ & \# & $\%$ & \# & $\%$ & \begin{tabular}{|l||}
$\#$ \\
\end{tabular} & \begin{tabular}{|l|l|}
$\%$ & $\mid$
\end{tabular} & \# & $\%$ & \begin{tabular}{|l||}
$\#$ \\
\end{tabular} & $\%$ & $\#$ & $\%$ & \# & $\%$ \\
\hline Tank & 1616 & $31.3 \%$ & 37 & $19.0 \%$ & 59 & $24.0 \%$ & 179 & $23.3 \%$ & 321 & $83.2 \%$ & 9 & $16.7 \%$ & 157 & $33.7 \%$ & 854 & 28.0\% \\
\hline Piping & 720 & $13.9 \%$ & 9 & $4.6 \%$ & 6 & $2.4 \%$ & 190 & $24.7 \%$ & 48 & $12.4 \%$ & 25 & $46.3 \%$ & 43 & $9.2 \%$ & 399 & $13.1 \%$ \\
\hline Dispenser & 655 & $12.7 \%$ & 38 & $19.5 \%$ & 31 & $12.6 \%$ & 160 & $20.8 \%$ & 8 & $2.1 \%$ & 9 & $16.7 \%$ & 49 & $10.5 \%$ & 360 & $11.8 \%$ \\
\hline \begin{tabular}{|l} 
STP \\
\end{tabular} & 76 & $1.5 \%$ & 4 & $2.1 \%$ & 2 & $0.8 \%$ & 36 & $4.7 \%$ & 1 & $0.3 \%$ & 5 & $9.3 \%$ & 9 & $1.9 \%$ & 19 & $0.6 \%$ \\
\hline Delivery Problem & 342 & $6.6 \%$ & 92 & $47.2 \%$ & 121 & $49.2 \%$ & 100 & $13.0 \%$ & 0 & $0.0 \%$ & 1 & $1.9 \%$ & 14 & $3.0 \%$ & 14 & $0.5 \%$ \\
\hline Other & 564 & $10.9 \%$ & 14 & $7.2 \%$ & 6 & $2.4 \%$ & 97 & $12.6 \%$ & 6 & $1.6 \%$ & 4 & $7.4 \%$ & 171 & $36.7 \%$ & 266 & $8.7 \%$ \\
\hline Unknown & 1195 & $23.1 \%$ & 1 & $0.5 \%$ & 21 & $8.5 \%$ & 8 & $1.0 \%$ & 2 & $0.5 \%$ & 1 & $1.9 \%$ & 23 & $4.9 \%$ & 1139 & $37.3 \%$ \\
\hline Totals & 5168 & & 195 & & 246 & & 770 & & 386 & & 54 & & 466 & & 3051 & \\
\hline
\end{tabular}

Source: Eighmey, C. LUSTLine Bulletin \#67. March 2011 


\section{Appendix B. Aboveground Compatibility}

\begin{tabular}{|c|c|c|c|c|c|}
\hline Manufacturer & Product & Model & $\mathrm{E} \%$ & UL listed & $\begin{array}{c}\text { UL listed } \\
\text { for this } \\
\text { fuel? }\end{array}$ \\
\hline Franklin Fueling & Shear valve & 662 models (UL listing for \#662502902) & E85 & yes & yes \\
\hline Franklin Fueling & Submersible turbine pump & FE Petro STPAG, IST & E85 & yes & yes \\
\hline Gilbarco & Dispenser, Retofit Kit & E25 option on any dispenser; E25 retrofit kit & E25 & yes & yes \\
\hline Gilbarco & Dispenser & Encore Flex Fuel & E85 & yes & yes \\
\hline EMCO Wheaton & Breakaway & A2119, A2219, A3019, A3219, A4119EVR & E15 & yes & no \\
\hline EMCO Wheaton & Breakaway & A4119-020E & E85 & no & \\
\hline EMCO Wheaton & Hose & all & E15 & yes & no \\
\hline EMCO Wheaton & Nozzle & $\begin{array}{l}\text { A4005-002, A4005-004, A4015-002, A4015- } \\
004\end{array}$ & E15 & yes & no \\
\hline EMCO Wheaton & Nozzle-balance vapor recov & A4005-002E, A4015-002E & E85 & yes & no \\
\hline EMCO Wheaton & Swivel & A0360 (not listed), A4110EVR (UL listing) & E15 & yes & no \\
\hline Husky & Nozzle & X E25, X E25, XSE25 & E25 & yes & yes \\
\hline Husky & Nozzle & $\begin{array}{l}\text { X E85, X E85 Cold Weather, XS E85, XS E85 } \\
\text { Cold Weather }\end{array}$ & E85 & yes & yes \\
\hline IRPCO & Hose-dispenser & $\begin{array}{l}\text { Steelflex Ultra Hardwall, Softwall (2 Braid, } \\
\text { 4SP), Marina }\end{array}$ & E15 & yes & no \\
\hline OPW & Breakaway & $66 \mathrm{~V}-0300$ & E25 & yes & yes \\
\hline OPW & Breakaway & $66 V-0492$ & E85 & yes & yes \\
\hline OPW & Nozzle & 21GE, 21GE-A & E85 & yes & yes \\
\hline OPW & Swivel & 241TPS-0492 & E85 & & \\
\hline OPW & Swivel & 241TPS-0241, 241TPS-1000, 241TPW-0492 & E25 & yes & yes \\
\hline OPW & Shear valve & 10P-0142E85, 10-P-4152E85 & E85 & yes & yes \\
\hline Veeder-Root & Submersible turbine pump & Redjacket, Redjacket AG, & E100 & yes & no \\
\hline Veyance & Hose & Flexsteel Futura Ethan-all & E85 & yes & yes \\
\hline Veyance & Hose & Flexsteel Futura & E15 & yes & no \\
\hline Wayne & Dispenser & E25 option on any dispenser; E25 retrofit kit & E25 & yes & yes \\
\hline Wayne & Dispenser & Ovation E85, Helix E85 & E85 & yes & yes \\
\hline
\end{tabular}

For compatibility of older dispensers with E85, please refer to: DOE Clean Cities. Handbook for Handling, Storing, and Dispensing E85 and Other Ethanol-Gasoline Blends. September 2013.

http://www.afdc.energy.gov/uploads/publication/ethanol handbook.pdf 


\section{Appendix C. Tank Compatibility}

\begin{tabular}{|c|c|}
\hline \multicolumn{2}{|r|}{ Tank Manufactuer Compability with Ethanol Blends } \\
\hline Manufacturer & Compatibility Statement with Ethanol Blends \\
\hline \multicolumn{2}{|l|}{ FIBERGLASS $^{1}$} \\
\hline Containment Solutions & Tanks manufactured after January 1, 1995 are all compatible with ethanol blends up to $100 \%$ (E100) (UL Listed) \\
\hline \multicolumn{2}{|l|}{ Owens Corning } \\
\hline Single Wall Tanks & Tanks manufactured between 1965 and 1994 are approved to store up to $10 \%$ ethanol (E10) \\
\hline \multirow{2}{*}{ Double Wall Tanks } & Tanks manufactured between 1965 and July 1, 1990 are approved to store up to $10 \%$ ethanol (E10) . \\
\hline & Tanks manufactured between July 2, 1990 and December 31, 1994 were warranted to store any ethanol blend. \\
\hline \multicolumn{2}{|l|}{ Xerxes } \\
\hline \multirow{3}{*}{ Single Wall Tanks } & Tanks manufactured prior to 1981 are not compatible with ethanol blends \\
\hline & $\begin{array}{l}\text { Tanks manufactured from February } 1981 \text { through June } 2005 \text { are designed for the storage of ethanol fuel up to a } \\
10 \% \text { blend (E10) }\end{array}$ \\
\hline & $\begin{array}{l}\text { Tanks manufactured from July } 2005 \text { to date are designed for the storage of ethanol fuel blends up to } 100 \% \\
\text { (E100) (UL Listed) }\end{array}$ \\
\hline \multirow[b]{2}{*}{ Double Wall Tanks } & Tanks manufactured prior to April 1990 were designed for the storage of ethanol fuel up to a $10 \%$ blend (E10) \\
\hline & $\begin{array}{l}\text { Tanks manufactured from April } 1990 \text { to date are designed for the storage of ethanol fuel blends up to } 100 \% \\
\text { (E100) (UL Listed) }\end{array}$ \\
\hline \multicolumn{2}{|l|}{ STEEL $^{2}$} \\
\hline Acterra Group Inc. & Compatible with all blends up to $100 \%$ (E100) \\
\hline Caribbean Tank Technologies Inc. & Compatible with all blends up to $100 \%$ (E100) \\
\hline Eaton Sales \& Service LLC & Compatible with all blends up to $100 \%$ (E100) \\
\hline General Industries & Compatible with all blends up to $100 \%$ (E100) \\
\hline Greer Steel, Inc. & Compatible with all blends up to $100 \%$ (E100) \\
\hline Hall Tank Co. & Compatible with all blends up to $100 \%$ (E100) \\
\hline Hamilton Tanks & Compatible with all blends up to $100 \%$ (E100) \\
\hline Highland Tank & Compatible with all blends up to $100 \%$ (E100) \\
\hline J.L. Houston Co. & Compatible with all blends up to $100 \%$ (E100) \\
\hline Kennedy Tank and Manufacturing Co. & Compatible with all blends up to $100 \%$ (E100) \\
\hline Lancaster Tanks and Steel Products & Compatible with all blends up to $100 \%$ (E100) \\
\hline Lannon Tank Corporation & Compatible with all blends up to $100 \%$ (E100) \\
\hline Mass Tank Sales Corp. & Compatible with all blends up to $100 \%$ (E100) \\
\hline Metal Products Company & Compatible with all blends up to $100 \%$ (E100) \\
\hline Mid-South Steel Products, Inc & Compatible with all blends up to $100 \%$ (E100) \\
\hline Modern Welding Company & Compatible with all blends up to $100 \%$ (E100) \\
\hline Newberry Tanks \& Equipment, LLC & Compatible with all blends up to $100 \%$ (E100) \\
\hline Plasteel $^{1}$ & Compatible with all blends up to $100 \%$ (E100) \\
\hline Service Welding \& Machine Company & Compatible with all blends up to $100 \%$ (E100) \\
\hline Southern Tank \& Manufacturing Co., Inc. & Compatible with all blends up to $100 \%$ (E100) \\
\hline Stanwade Metal Products & Compatible with all blends up to $100 \%$ (E100) \\
\hline Talleres Industriales Potosinos & Compatible with all blends up to $100 \%$ (E100) \\
\hline Tanques Antillanos C. xA. & Compatible with all blends up to $100 \%$ (E100) \\
\hline Watco Tanks, Inc. & Compatible with all blends up to $100 \%$ (E100) \\
\hline We-Mac Manufacturing Company & Compatible with all blends up to $100 \%$ (E100) \\
\hline \multicolumn{2}{|c|}{$\begin{array}{l}\text { Letters stating compability } \\
1 \text { PEI http://www.pei.org/PublicationsResources/ComplianceFunding/USTComponentCompatibilityLibrary/tabid/882/Default.aspx } \\
2 \text { STI http://www.steeltank.com/Publications/E85BioDieselandAlternativeFuels/ManufacturerStatementsofCompatibility/tabid/468/Default.aspx }\end{array}$} \\
\hline
\end{tabular}




\section{Appendix D. Pipe Compatibility}

\begin{tabular}{|c|c|c|c|c|c|}
\hline Manufacturer & Product & Model & $E \%$ & UL listed & $\begin{array}{l}\text { UL listed } \\
\text { for this } \\
\text { fuel? }\end{array}$ \\
\hline Advantage Earth Products & Pipe & $1.5^{\prime \prime}, 2^{\prime \prime}, 3 ", 4 "$ & E100 & yes & yes \\
\hline Brugg Pipesystems & Pipe & FLEXWELL-HL, SECON-X, NIROFLEX, LPG & E100 & yes & yes \\
\hline Franklin Fueling & Pipe & XP, UPP & E100 & yes & yes \\
\hline Franklin Fueling & Pipe ducting & APT, UPP & E100 & yes & yes \\
\hline Franklin Fueling & Pipe fittings & $\begin{array}{l}\text { XP stainless steel (ELB-XP-150, ELB-XP- } \\
175, \text { ELB-XP-200, GSHP-150, GSHP-200, } \\
\text { MS-XP-150-150SS, MS-XP-175-200SS, MS- } \\
\text { XP-200-200SS, MS-100-100SS, MS-XP- } \\
\text { 150-150, MS-XP-SW-175-200, MS-XP-SW- } \\
200-200, \text { QRS-XP-150-200, QRS-XP-175- } \\
\text { 200, QRS-XP-200-200, SSC-150, SSC-200, } \\
\text { SSE90-150, SSE90-200, SSE90-150, SST- } \\
\text { 150, SST-200, SSU-150, SSSHP-150, TEE- } \\
\text { XP-150, TEE-XP-175, TEE-XP-200) UPP } \\
\text { stainless fittings }\end{array}$ & E85 & yes & yes \\
\hline NOV Fiberglass & Red Thread IIA & fiberglass & E100 & yes & yes \\
\hline NUPI & Smartflex & flexible plastic & E100 & yes & yes \\
\hline OMEGAFLEX & DoubleTrac & $\begin{array}{l}\text { flexible plastic (must use stainless steel } \\
\text { fittings) }\end{array}$ & E100 & yes & yes \\
\hline OPW & Pipe & FlexWorks, Pisces (discontinued) & E100 & yes & yes \\
\hline OPW & \begin{tabular}{|l|} 
Pipe adaptors, \\
couplers, fittings
\end{tabular} & FlexWorks & E100 & yes & yes \\
\hline
\end{tabular}




\section{Appendix E. Other UST Equipment Compatibility}

Note: "UN" in the E\% column indicates the manufacturer does not know if it is compatible with ethanol blends. ? = waiting on information from OEM

\begin{tabular}{|c|c|c|c|c|c|c|}
\hline Manufacturer & Product & Model & E\% & $\begin{array}{c}\text { UL } \\
\text { Listed }\end{array}$ & $\begin{array}{c}\text { UL listed } \\
\text { for this } \\
\text { fuel }\end{array}$ & $\begin{array}{l}\text { Other } \\
\text { Approval }\end{array}$ \\
\hline Clay and Bailey & AST anti-siphon valve & 405 & E10 & no & & \\
\hline Clay and Bailey & AST manhole & API-650 & E85 & no & & \\
\hline Clay and Bailey & AST alarm & 1400 & E10 & no & & \\
\hline Clay and Bailey & AST overfill prevention valve & 1228 & E85 & yes & no & \\
\hline Clay and Bailey & AST pressure vacuum vent & 88 & E10 & no & & \\
\hline Clay and Bailey & AST spill contaiment & all & E85 & no & & \\
\hline Clay and Bailey & AST emergency vent & $354,365,366,367,368,369,370$ & E85 & yes & no & \\
\hline Clay and Bailey & Manhoes & all & E10 & no & & \\
\hline Clay and Bailey & Ball valve & 736 & E10 & no & & \\
\hline Clay and Bailey & Fill cap & $94,232,233,234,235,254$ & E85 & no & & \\
\hline Clay and Bailey & Vent-upflow & 395 & E10 & no & & \\
\hline Cimtek & Filter & $300,400,450,475$ & E15 & yes & no & \\
\hline Cimtek & Filter & 800 & E85 & yes & no & \\
\hline EMCO Wheaton & Nozzle-balance vapor recovery & A4005-002E, A4015-002E & E85 & yes & no & CARB EVR \\
\hline EMCO Wheaton & Nozzle-balance vapor recovery & $\begin{array}{l}\text { A4005-002, A4005-004, A4015-002, } \\
\text { A4015-004 }\end{array}$ & E15 & yes & no & CARB EVR \\
\hline EMCO Wheaton & Breakaway & A4119-020E & E85 & no & & \\
\hline EMCO Wheaton & Breakaway & $\begin{array}{l}\text { A2119, A2219, A3019, A3219, } \\
\text { A4119EVR }\end{array}$ & E15 & yes & no & $\begin{array}{l}\text { CARB EVR } \\
\text { (A4119 only) }\end{array}$ \\
\hline EMCO Wheaton & Swivel & A0360, A4110EVR & E15 & \begin{tabular}{|l|} 
yes \\
(EVR \\
only) \\
\end{tabular} & no & $\begin{array}{l}\text { CARB EVR } \\
\text { (A4110 only) }\end{array}$ \\
\hline EMCO Wheaton & Hose & all & E15 & yes & no & \\
\hline EMCO Wheaton & Adaptors & $\begin{array}{l}\text { A0030, A0030-142, A0076, A0076-142S } \\
\text { A0089, A0096, }\end{array}$ & E15 & no & & $\begin{array}{l}\text { CARB EVR } \\
\text { (both A0030 } \\
\text { and A0076) }\end{array}$ \\
\hline EMCO Wheaton & Ball float & A0075E, A0078E & E85 & no & & $\begin{array}{l}\text { CARB EVR } \\
(\mathrm{A} 0078)\end{array}$ \\
\hline EMCO Wheaton & Ball float & $\mathrm{A} 0075, \mathrm{~A} 0078$ & E15 & no & & $\begin{array}{l}\text { CARB EVR } \\
(\mathrm{A} 0078)\end{array}$ \\
\hline EMCO Wheaton & Caps & $\begin{array}{l}\text { A0097-005, A0097-004LP, A0097-010, } \\
\text { A0099-002, A0099-004LP }\end{array}$ & E15 & no & & $\begin{array}{l}\text { CARB EVR } \\
\text { (A0097-005, } \\
\text { A0099-02) } \\
\end{array}$ \\
\hline EMCO Wheaton & Drop tube & A0020-004E, A0020-005E, A0020-007E & E15 & no & & $\begin{array}{l}\text { CARB EVR } \\
\text { (A0020, } \\
\text { A0088) }\end{array}$ \\
\hline EMCO Wheaton & Drop tube & $\begin{array}{l}\text { A0020-004, A0020-005, A0020-007, } \\
\text { A0020-008, A0020-021, A0020-133, } \\
\text { A0020-144, A0070, A0088 }\end{array}$ & E15 & no & & $\begin{array}{l}\text { CARB EVR } \\
\text { (A0020, } \\
\text { A0088) } \\
\end{array}$ \\
\hline EMCO Wheaton & Extractor fittings & A0079 & E85 & yes & no & CARB EVR \\
\hline EMCO Wheaton & Overfill prevention valve & \begin{tabular}{|l|} 
A1100-010E, A1100-056SE, A1100- \\
055SERF, A1100-056SERF, A1100EVR- \\
057E, A1100-067E, A1100-087E
\end{tabular} & E85 & no & & CARB EVR \\
\hline EMCO Wheaton & Overfill prevention valve & $\begin{array}{l}\text { A1100-010, A1100-011, A1100-054S, } \\
\text { A1100-054SC, A1100-054SCN, A1100- } \\
\text { 055SRF, A1100-056SRF, A1100-053S, } \\
\text { A1100-055S, A1100EVR-055, A1100- } \\
\text { 056S, A1100EVR-056, A1100-057S, } \\
\text { A1100EVR-057, A1100-058S, } \\
\text { A1100EVR-058, A1100-065S, A1100- } \\
\text { 066S, A1100-067S, A1100-085S, A1100- } \\
\text { 087S, A1100-087S } \\
\end{array}$ & E15 & no & & $\begin{array}{l}\text { CARB EVR } \\
\text { (only models } \\
\text { with EVR in } \\
\text { model no.) }\end{array}$ \\
\hline EMCO Wheaton & Ball valve & A0750 & E15 & no & & \\
\hline EMCO Wheaton & Check valve & A0066, A0732 & E15 & no & & \\
\hline EMCO Wheaton & Shear valve & A0060 with stainless steel body & E85 & yes & no & \\
\hline EMCO Wheaton & Shear valve & A0060 with cast iron body, A0063 & E15 & yes & no & \\
\hline EMCO Wheaton & Vent & A0084, A0085, A4103, A0785 & E15 & \begin{tabular}{|l|} 
yes \\
(A4103 \\
only) \\
\end{tabular} & no & \\
\hline Husky & Pressure vacuum vents & $4620,4885,5885,8060$ & E85 & \begin{tabular}{|l|l} 
yes \\
\end{tabular} & yes & \\
\hline
\end{tabular}




\begin{tabular}{|c|c|c|c|c|c|c|}
\hline Manufacturer & Product & Model & $E \%$ & $\begin{array}{c}\text { UL } \\
\text { listed }\end{array}$ & $\begin{array}{l}\text { UL listed } \\
\text { for this } \\
\text { fuel? }\end{array}$ & $\begin{array}{l}\text { Other } \\
\text { Approval }\end{array}$ \\
\hline \multicolumn{7}{|l|}{ STP Equipment } \\
\hline Franklin Fueling & Mechanical line leak detector & MLD+AG & E85 & yes & $?$ & \\
\hline Franklin Fueling & Mechanical line leak detector & STP-MLD & E10 & yes & yes & \\
\hline Franklin Fueling & Shear valve (emergency shear & 662 models & E85 & \begin{tabular}{|l|} 
yes \\
$(66250$ \\
$2902)$ \\
\end{tabular} & yes & \\
\hline Franklin Fueling & Shear valve-vapor & 362 models & UN & no & & \\
\hline Franklin Fueling & Submersible pump controller & MagVFC IST, & E85 & yes & & \\
\hline Franklin Fueling & Submersible turbine pump & STP & E10 & yes & yes & \\
\hline Franklin Fueling & Submersible turbine pump & FE Petro STPAG, IST & E85 & yes & yes & \\
\hline \multicolumn{7}{|l|}{ Fill Equipment } \\
\hline Franklin Fueling & Ball float vent valve & 308 models & E85 & no & & EVR CARB \\
\hline Franklin Fueling & Drop tube & $\begin{array}{l}306 \text { and } 708 \text { models, 782-204-30-2, 782- } \\
204-32-2,782-202-12,782-203-12,782- \\
204-10-2,782-204-12-2,782-204-15-2\end{array}$ & E85 & no & & \\
\hline Franklin Fueling & Extractor vent valve (tee) & 300 series models & E85 & no & & \\
\hline Franklin Fueling & Fill adaptor-side & 776-300-01, 776-300-31 & E85 & no & & \\
\hline Franklin Fueling & Fill adaptor-swivel & SWF-100-SS, SWFV-PKGSS & E85 & no & & EVR CARB \\
\hline Franklin Fueling & Fill adaptor-swivel & SWFV-PKG, 705-412-01, 705-412-02 & E85 & no & & \\
\hline Franklin Fueling & Fill adaptor-top & $778-301-05$ & E85 & no & & EVR CARB \\
\hline Franklin Fueling & Fill adaptor-top & $\begin{array}{l}776-300-01,776-300-31,778-301-01, \\
778-301-02,778-301-06,778-301-32, \\
778-301-01,778-302-31,778-303-02, \\
778-303-32,780-200-01\end{array}$ & E85 & no & & \\
\hline Franklin Fueling & Fill cap-side & 775 series & E85 & no & & \\
\hline Franklin Fueling & Fill cap-top & 777-201-02 & E85 & no & & EVR CARB \\
\hline Franklin Fueling & Fill cap-top & $\begin{array}{l}\text { 777-202-01, 777-202-02, 779-200-01, } \\
774-202-03\end{array}$ & E85 & no & & \\
\hline Franklin Fueling & Vapor cap & $304-301-03$ & E85 & no & & EVR CARB \\
\hline Franklin Fueling & Vapor cap & $\begin{array}{l}\text { 304-200-01, 304-200-02, 304-301-01, } \\
304-301-02\end{array}$ & E10 & no & & $\begin{array}{l}\text { EVR CARB } \\
(301-01 \\
\text { only) }\end{array}$ \\
\hline Franklin Fueling & Vapor pipe adaptor & SWV-101-SS, SWFV-PKGSS & E85 & no & & EVR CARB \\
\hline Franklin Fueling & Vapor pipe adaptor & $\begin{array}{l}\text { SWV-101-B, SWFV-PKG, 705-413-01, } \\
\text { 705-413-02 }\end{array}$ & E10 & no & & \\
\hline Franklin Fueling & Vapor recovery adaptor & 306 and 708 models & E85 & no & & \\
\hline Franklin Fueling & Overfill prevention valve & $\begin{array}{l}\text { 708-491-31, 708-491-32, 708-492-21, } \\
708-492-22,708-492-31,708-492-32, \\
708-498-11\end{array}$ & E85 & yes & $?$ & $\begin{array}{l}\text { EVR CARB } \\
\text { (ending in } \\
11 \text { or } 12 \text { ) }\end{array}$ \\
\hline Franklin Fueling & Overfill prevention valve & $\begin{array}{l}708-491-01,708-491-02,708-491-11 \\
708-491-12,708,491-21,708-492-01 \\
708-492-02,708-498-11,708-493-03, \\
708-493-04,708-493-23,708-493-24, \\
708-340-901,708-494-02,708-494-03 \\
708-494-04,708-498-01,708-498-02 \\
708-498-03\end{array}$ & E10 & yes & $?$ & EVR CARB \\
\hline Franklin Fueling & Probe cap and adaptor kit & $90037-\mathrm{E}$ & E85 & no & & EVR CARB \\
\hline Franklin Fueling & Spill container (bucket) & $702,703,705,715$ & E10 & \begin{tabular}{|l|} 
yes \\
$(705$ \\
and \\
715 \\
models \\
only) \\
\end{tabular} & & $\begin{array}{l}\text { yes (705 } \\
\text { and } 715 \\
\text { models only) }\end{array}$ \\
\hline Franklin Fueling & Spill container (bucket) & Phil-Tite series, Defender Series & E85 & yes & $?$ & EVR CARB \\
\hline Franklin Fueling & Tank bottom protector & TBP-3516-E & E85 & no & & \\
\hline Franklin Fueling & Tank bottom protector & $785-200-02$ & E10 & no & & \\
\hline Franklin Fueling & Vent valve (pressure/vacuum) & PV-ZERO models & E85 & yes & $?$ & EVR CARB \\
\hline
\end{tabular}




\begin{tabular}{|c|c|c|c|c|c|c|}
\hline Manufacturer & Product & Model & $\mathrm{E} \%$ & $\begin{array}{c}\text { UL } \\
\text { listed }\end{array}$ & $\begin{array}{c}\text { UL listed } \\
\text { for this } \\
\text { fuel? }\end{array}$ & $\begin{array}{c}\text { Other } \\
\text { Approval }\end{array}$ \\
\hline \multicolumn{7}{|l|}{ UST Equipment } \\
\hline Franklin Fueling & API adaptor & $880-500-04$ & E85 & no & & \\
\hline Franklin Fueling & Automatic tank gauge & TSP & E10 & yes & yes & \\
\hline Franklin Fueling & Ball valve (for pipe) & FLEX-ING & E85 & yes & no & CSA \\
\hline Franklin Fueling & Check valve & $622-300-01,65,515,516,615,635,650$ & E10 & no & & \\
\hline Franklin Fueling & Dispensing cutoff system & DC400 & E10 & no & & \\
\hline Franklin Fueling & Flexible connectors & FLEX-ING & E10 & & & \\
\hline Franklin Fueling & Flexible connectors & FIREFLEX & E85 & yes & no & \\
\hline Franklin Fueling & Float kit & TSP-IGF4P & E15 & no & & \\
\hline Franklin Fueling & Float kit & TSP-IGF4D3, TSP-IGF4D & E85 & no & & \\
\hline Franklin Fueling & Foot valve & $50-201,320$ & E10 & no & & \\
\hline Franklin Fueling & Interstitial sensor & TSP-HIS, TSP-DIS, TSP-EIS, TSP-HFS & E85 & no & & \\
\hline Franklin Fueling & Level sensor & TSP-HLS & E85 & no & & \\
\hline Franklin Fueling & Magnostrictive probe & Moorman & E85 & no & & \\
\hline Franklin Fueling & Manhole & $\begin{array}{l}\text { 14U, 20UR, 780, 781, 789, 808, 810, } \\
\text { 814, 987, Defender, SSQ, SR series }\end{array}$ & E10 & no & & \\
\hline Franklin Fueling & Monitoring test well & $772,773,808,810$ & E10 & no & & \\
\hline Franklin Fueling & Monitoring well cap & TSP-KW4 & E10 & no & & \\
\hline Franklin Fueling & Monitoring well sensor & TSP-MWS & E0 & no & & \\
\hline Franklin Fueling & Probe installation kit & FFS & E10 & no & & \\
\hline Franklin Fueling & Pipe fittings & $\begin{array}{l}\text { GC-150, GC-200, GE90-150, GE90-200, } \\
\text { GE90-215, GE90-252, GHB-200-150, GT } \\
\text { 150, GT-200, GT-215, GT-252, GU-150, } \\
\text { GU-200, GHB-200-150, GSHP-150, } \\
\text { GSHP-200, XP brass (MS-XP-150-150, } \\
\text { MS-XP-175-200, MS-XP-200-200 }\end{array}$ & E10 & yes & yes & \\
\hline Franklin Fueling & Sumps & $\begin{array}{l}\text { 2400, } 4542(\mathrm{UL}), 4736, \mathrm{APT}, \mathrm{AST}, \mathrm{LM}, \\
\text { TS, UPP (UL) models }\end{array}$ & E85 & yes & no & \\
\hline Franklin Fueling & $\begin{array}{l}\text { Sump accessories, fittings, } \\
\text { boots }\end{array}$ & C & E85 & yes & no & \\
\hline \multicolumn{7}{|c|}{ Above-ground Equipment } \\
\hline Franklin Fueling & Nozzle & $\begin{array}{l}400,600,708,709,800,900 \text { series (all } \\
\text { vapor recovery II) }\end{array}$ & E10 & no & & $\begin{array}{l}\text { EVR CARB } \\
(400,600, \\
900)\end{array}$ \\
\hline Franklin Fueling & Breakaway & $\begin{array}{l}\text { 697, 698, ACCUBREAK, SAFETY- } \\
\text { SEVER }\end{array}$ & E10 & yes & yes & \\
\hline Franklin Fueling & Hoses & FLEX-ING & E10 & no & & \\
\hline Franklin Fueling & Hoses & FLEX-ON & E15 & yes & no & \\
\hline Franklin Fueling & Swivel & 465 & E10 & no & & \\
\hline Franklin Fueling & Swivel & FLEX-ING multi-plane & E10 & no & & \\
\hline \multicolumn{7}{|l|}{ AST Equipment } \\
\hline Franklin Fueling & Anti-siphon valve & 636-300-11, 636-300-12 & E85 & no & & \\
\hline Franklin Fueling & Anti-siphon valve & $\begin{array}{l}605-300-01,606-300-01,616-300-01 \\
616-300-02,616-300-03\end{array}$ & E10 & no & & API/RP 2000 \\
\hline Franklin Fueling & AST emergency vent & 803 & E10 & yes & & \\
\hline Franklin Fueling & AST fill cap & 751,770 & E10 & no & & \\
\hline Franklin Fueling & AST overfill prevention valve & 709 & E10 & no & & \\
\hline Franklin Fueling & AST Pressure regulator valve & $620,621,622,644$ & E10 & yes & & API/RP 2000 \\
\hline Franklin Fueling & AST pressure vacuum vent & 802 & E10 & no & & \\
\hline Franklin Fueling & AST spill container (bucket) & 706 & E10 & no & & \\
\hline Franklin Fueling & AST tank vent & 800 & E10 & no & & \\
\hline
\end{tabular}




\begin{tabular}{|c|c|c|c|c|c|c|}
\hline Company & Product & Model & $E \%$ & $\begin{array}{c}\text { UL } \\
\text { Listed }\end{array}$ & $\begin{array}{c}\text { UL listed } \\
\text { for this } \\
\text { fuel }\end{array}$ & $\begin{array}{l}\text { Other } \\
\text { Approval }\end{array}$ \\
\hline Morrison Bros & Adaptor-coaxial & 605 & UN & no & & \\
\hline Morrison Bros & Anodized Farm Nozzle & $200 S$ & E85 & no & & \\
\hline Morrison Bros & Anti-Syphon Valve & 912 & E85 & no & & \\
\hline Morrison Bros & AST adaptor & 927 & E85 & no & & $\begin{array}{l}\text { EVR CARBa } \\
\text { (some) }\end{array}$ \\
\hline Morrison Bros & AST adaptor & 926, 927B & UN & no & & \\
\hline Morrison Bros & AST clock gauge & $\begin{array}{l}\text { 818, 818C, 818F, 818MET, } \\
\text { 818MEF, 918F, 918FT, } \\
\text { 918MEF, 918MET, 918T, } \\
\text { 1018GM, 8181 }\end{array}$ & UN & no & & $\begin{array}{l}\text { EVR CARBa } \\
\text { (some) }\end{array}$ \\
\hline Morrison Bros & Ball Valves & 691BSS & E85 & no & & \\
\hline Morrison Bros & Cap relief & 779 & UN & no & & \\
\hline Morrison Bros & Caps & $305 \mathrm{C}$ & E85 & no & & $\begin{array}{l}\text { EVR CARBa } \\
\text { (some) }\end{array}$ \\
\hline Morrison Bros & Caps-monitoring well & 305XP, 305XPU & UN & \begin{tabular}{|l} 
yes \\
(XPU)
\end{tabular} & & $\begin{array}{l}\text { EVR CARBa } \\
\text { (some) }\end{array}$ \\
\hline Morrison Bros & Cap-test well & $\begin{array}{l}\text { 178XAT, 178XB, 178XA, } \\
\text { 305XA, 678XA }\end{array}$ & UN & no & & \\
\hline Morrison Bros & Clock Gauge with Alarm & 918 & E85 & no & & \\
\hline Morrison Bros & Clock Gauges & 818 & E85 & no & & \\
\hline Morrison Bros & Combination Vent/Overfill Alarm & 922 & E85 & no & & \\
\hline Morrison Bros & Diffuser & 539TO, 539ТС & E85 & no & & $\begin{array}{l}\begin{array}{l}\text { EVR CARBa } \\
\text { (some) }\end{array} \\
\end{array}$ \\
\hline Morrison Bros & Diffuser & 539, 539EXT, 539TC, 539TO & UN & no & & $\begin{array}{l}\text { EVR CARBa } \\
\text { (some) }\end{array}$ \\
\hline Morrison Bros & Double Tap Bushing & 184 & E85 & no & & \\
\hline Morrison Bros & Drop Tubes & $419 \mathrm{~A}$ & E85 & no & & \\
\hline Morrison Bros & Drop tubes & $275,419,419$ SOS & UN & no & & $\begin{array}{l}\text { EVR CARBa } \\
\text { (some) }\end{array}$ \\
\hline Morrison Bros & Emergency Vents & 244 & E85 & yes & yes & $\begin{array}{l}\text { EVR CARBa } \\
\text { (some) }\end{array}$ \\
\hline Morrison Bros & Expansion Relief Valve & 076DI, 078DI & E85 & no & & \\
\hline Morrison Bros & External Emergency Valves & $\begin{array}{l}\text { 346DI, 346FDI, 346SS, } \\
\text { 346FSS }\end{array}$ & E85 & no & & \\
\hline Morrison Bros & Extractor pipe cap & $578,578 \mathrm{P}$ & UN & no & & \\
\hline Morrison Bros & Extractors & $560 / 561 / 562 / 563$ & E85 & no & & \\
\hline Morrison Bros & Fill cap & $\begin{array}{l}178,178 \mathrm{DT}, 179,179 \mathrm{Cl}, \\
179 \mathrm{M}, 179 \mathrm{MCl}, 180 \mathrm{M}, 305 \mathrm{CU}, \\
379,405 \mathrm{C}\end{array}$ & UN & no & & $\begin{array}{l}\text { EVR CARBa } \\
\text { (some) }\end{array}$ \\
\hline Morrison Bros & Fill cap and adaptor & 307 & UN & no & & \\
\hline Morrison Bros & Fill swivel adaptor & $305 \mathrm{SA}$ & UN & no & & \\
\hline Morrison Bros & Flame Arrester & $351 \mathrm{~S}$ & E85 & no & & \\
\hline Morrison Bros & Float Vent Valves & 317 & E85 & no & & \\
\hline Morrison Bros & Frost Proof Drain Valve & 128DIS & E85 & no & & \\
\hline Morrison Bros & Indicator paste & 490G, 490W, SAR-GEL & UN & no & & \\
\hline Morrison Bros & \begin{tabular}{|l|} 
In-Line Check Valve \\
\end{tabular} & 958 & E85 & no & & \\
\hline Morrison Bros & Internal Emergency Valves & $272 \mathrm{DI}, 72 \mathrm{HDI}$ & E85 & no & & \\
\hline Morrison Bros & Interstitial sensor & 918TCPS, 924LS & UN & no & & \\
\hline Morrison Bros & Manholes & $\begin{array}{l}\text { 318, 318L, 318TM, 318VR, } \\
\text { 318XA, 418, 418L, 418TM, } \\
\text { 418XA, 418XAP, 418XAH, } \\
\text { 418XAW, 418LC, 424, 519, } \\
\text { 524, 524H }\end{array}$ & UN & no & & \\
\hline
\end{tabular}




\begin{tabular}{|c|c|c|c|c|c|c|}
\hline Company & Product & Model & $E \%$ & $\begin{array}{c}\text { UL } \\
\text { Listed }\end{array}$ & $\begin{array}{c}\text { UL listed } \\
\text { for this } \\
\text { fuel }\end{array}$ & $\begin{array}{l}\text { Other } \\
\text { Approval }\end{array}$ \\
\hline Morrison Bros & Mechanical gauge & 1018GM & UN & no & & \\
\hline Morrison Bros & Overfill Alarm & 918TCP & E85 & no & & \\
\hline Morrison Bros & Overfill Prevention Valve & 9095A-AV, 9095SS & E85 & no & & \\
\hline Morrison Bros & Overfill Prevention Valve & 9095AA, 9095GBT & E85 & no & & \\
\hline Morrison Bros & Pressure Vacuum Vent & 948A & E85 & yes & yes & \\
\hline Morrison Bros & Probe cap and adaptor & $307 \mathrm{P}$ & UN & no & & \\
\hline Morrison Bros & $\begin{array}{l}\text { Solenoid Valves (3" Must be all } \\
\text { Teflon version) }\end{array}$ & $710 S S$ & E85 & no & & \\
\hline Morrison Bros & Spill Containers & $515 / 516 / 517 / 518$ & E85 & no & & \begin{tabular}{|l} 
EVR CARBa \\
$(516)$
\end{tabular} \\
\hline Morrison Bros & Strainer & 285 & E85 & no & & \\
\hline Morrison Bros & Strainer & \begin{tabular}{|l|} 
284B, 284S, 285AL, 285DI, \\
285FDI, 286, 286FDI, 286U
\end{tabular} & UN & no & & \\
\hline Morrison Bros & Swing Check Valves & 246ADI, 246DRF & E85 & no & & \\
\hline Morrison Bros & Tank gauge & 618 & UN & no & & \\
\hline Morrison Bros & Tank Monitor Adaptor and Cap & 305XPA & E85 & no & & \\
\hline Morrison Bros & Vapor Recovery Adaptor & 323 & E85 & no & & EVR CARBa \\
\hline Morrison Bros & Vapor Recovery Caps & $323 \mathrm{C}$ & E85 & no & & \\
\hline Morrison Bros & Vent-double outlet (small UST) & 155 & E85 & no & & \\
\hline Morrison Bros & Vent-double outlet (small UST) & 155S, 155FA & UN & no & & \\
\hline Morrison Bros & Vent-pressure vacuum & $548,748,749$ & E85 & no & & \\
\hline Morrison Bros & Vent-updraft & 354 & E85 & no & & \\
\hline Morrison Bros & Vent-updraft & $354 \mathrm{~T}$ & UN & no & & \\
\hline Morrison Bros & & $571,571 \mathrm{P}$ & UN & no & & \\
\hline $\begin{array}{l}\text { National } \\
\text { Environmental } \\
\text { Fiberglass }\end{array}$ & Sumps-tank & All & E85 & yes & no & EVR CARB \\
\hline $\begin{array}{l}\text { National } \\
\text { Environmental } \\
\text { Fiberglass }\end{array}$ & Sumps-transition & All & E85 & yes & no & EVR CARB \\
\hline $\begin{array}{l}\text { National } \\
\text { Environmental } \\
\text { Fiberglass }\end{array}$ & Sumps-dispenser & All & E85 & yes & no & EVR CARB \\
\hline
\end{tabular}




\begin{tabular}{|c|c|c|c|c|c|c|}
\hline Company & Product & Model & $\mathrm{E} \%$ & $\begin{array}{c}\text { UL } \\
\text { Listed }\end{array}$ & $\begin{array}{c}\text { UL listed } \\
\text { for this } \\
\text { fuel }\end{array}$ & $\begin{array}{l}\text { Other } \\
\text { Approval }\end{array}$ \\
\hline \multicolumn{7}{|c|}{ Above Ground Equipment } \\
\hline OPW & Balance Adaptor & $28 \mathrm{CS}$ & E25 & no & & \\
\hline OPW & Breakaway & $66 \mathrm{~V}-0492$ & E85 & yes & yes & \\
\hline OPW & Breakaway & 66V-030RF & E25 & yes & yes & \\
\hline OPW & Breakaway & $\begin{array}{l}\text { 66V-0300, 66RB-2000, 68EZR- } \\
\text { 7575, 66REC-1000, 66SB- } \\
\text { 7575, 66SB-1010, 66CAS- } \\
\text { 0300, 66ISU-5100, 66ISB- } \\
\text { 5100, MFVA, 66CLP-5100, } \\
\text { 66CSU-5200 }\end{array}$ & E10 & yes & yes & \\
\hline OPW & nozzle & 21GE-0992 & E85 & yes & yes & \\
\hline OPW & Nozzle & $\begin{array}{l}\text { 11AP-0100-E25, 11AP-0300- } \\
\text { E25, 11AP-0400-E25, 11AP- } \\
\text { 0900-E25, 11BP-0100-E25, } \\
\text { 11BP-0300-E25, 11BP-0400- } \\
\text { E25, 11BP-0900-E25 }\end{array}$ & E25 & yes & yes & \\
\hline OPW & Nozzle & 11AP / 11BP Series & E10 & yes & yes & \\
\hline OPW & Swivel & 241TPS-75RF & E25 & yes & yes & \\
\hline OPW & Swivel & \begin{tabular}{|l|}
$36 \mathrm{~S}$ series, $241 \mathrm{TPS}$ series, \\
$20 \mathrm{~S}$ series, 45 series \\
\end{tabular} & E10 & yes & yes & \\
\hline OPW & Swivel & 241TPS-0492 & E85 & yes & yes & \\
\hline OPW & Emergency shear valve & 10 series & E100 & yes & no & \\
\hline OPW & Vapor shear valve & $60 \mathrm{VS}$ & E100 & yes & no & EVR CARBa \\
\hline \multicolumn{7}{|l|}{ AST Equipment } \\
\hline OPW & AST anti-siphon valve & 199ASV & E85 & yes & no & \\
\hline OPW & AST ball valve & $21 \mathrm{BV} S \mathrm{~S}$ & E85 & yes & no & \\
\hline OPW & AST check valve & 175,1175 & E85 & no & no & \\
\hline OPW & Drop tube & $61 \mathrm{FT}$ & E25 & no & no & EVR CARBa \\
\hline OPW & AST emergency shut off valve & $178 \mathrm{~S}$ & E85 & no & no & \\
\hline OPW & AST emergency vent & 201,202 & E85 & yes & no & \\
\hline OPW & AST emergency vent & 301 & E86 & yes & no & EVR CARBa \\
\hline OPW & AST mechanical gauge & 200TG & E85 & yes & no & EVR CARBa \\
\hline OPW & AST overfill prevention valve & 61fSTOP A or M versions & E85 & yes & no & EVR CARBa \\
\hline OPW & AST overfill prevention valve & $61 f S T O P$ & E25 & yes & no & \\
\hline OPW & AST pressure vacuum vent & $523 \mathrm{~V}, 623 \mathrm{~V}$ & E100 & yes & no & \\
\hline OPW & AST solenoid valve & 821 & E25 & yes & no & \\
\hline OPW & AST spill container & 211-RMOT, 331, 332 & E85 & yes (uld & no & EVR CARBa \\
\hline OPW & AST swing check valve & all & E85 & \begin{tabular}{|l|l} 
no \\
\end{tabular} & no & \\
\hline OPW & AST tank alarm & 444TA & E85 & no (ETL & no & \\
\hline OPW & AST vapor adaptor & 1611AVB-1625 & E85 & no & & \\
\hline OPW & AST vapor cap & $\begin{array}{l}\text { 1711T-7085-EVR, 1711LPC- } \\
0300\end{array}$ & E85 & no & & \\
\hline
\end{tabular}




\begin{tabular}{|c|c|c|c|c|c|c|}
\hline Company & Product & Model & $\mathrm{E} \%$ & $\begin{array}{c}\text { UL } \\
\text { Listed }\end{array}$ & $\begin{array}{c}\text { UL listed } \\
\text { for this } \\
\text { fuel }\end{array}$ & $\begin{array}{l}\text { Other } \\
\text { Approval }\end{array}$ \\
\hline \multicolumn{7}{|c|}{ UST Equipment } \\
\hline \multicolumn{7}{|c|}{ Caps and adaptors } \\
\hline OPW & Fill adaptor-top & 633T, 633TC & $?$ & yes & no & \\
\hline OPW & Fill-swivel adaptor & $\begin{array}{l}\text { 61SALP-MA, 61SALP-1020- } \\
\text { EVR }\end{array}$ & E85 & yes & no & CARB EVR \\
\hline OPW & Vapor swivel adaptor & $61 \mathrm{VSA}$ & $?$ & yes & no & CARB EVRa \\
\hline OPW & Fill-swivel adaptor (vapor) & 61VSA-MA, 61VSA-1020-EVR & E85 & yes & no & CARB EVR \\
\hline OPW & Fill cap-side & $62 \pi$ & $?$ & yes & no & \\
\hline OPW & Fill adaptor-side & $61 \mathrm{AS}$ & $?$ & yes & no & \\
\hline OPW & Vapor adaptor & 1611AV, 1611AVB & E100 & yes & no & CARB EVR \\
\hline OPW & Vapor Cap & $1711 \mathrm{~T}$ & E85 & yes & no & $\begin{array}{l}\text { CARB EVR } \\
\end{array}$ \\
\hline OPW & Monitoring well probe cap & $62 \mathrm{M}, 116 \mathrm{M}$ & E100 & yes & no & \\
\hline OPW & Monitoring well probe cap & $62 \mathrm{M}-\mathrm{MA}$ & E85 & yes & no & CARB EVR \\
\hline OPW & Monitoring well cap kit & 634TTM, 62PMC & $?$ & yes & no & \\
\hline OPW & Monitoring test well & 61SPVC & $?$ & no & & \\
\hline \multicolumn{7}{|c|}{ Extractors, Manholes, Multi-ports } \\
\hline OPW & Extractor fittings and plug & $233,233 \mathrm{VP}$ & E85 & no & & CARB EVR \\
\hline OPW & Multi-port spill containment & $411,511,521$, Fiberlite, & E100 & no & & CARB EVR \\
\hline OPW & Jack screw & 71JSK & E85 & no & & \\
\hline OPW & Jack screw & 61JSK & $?$ & no & & \\
\hline OPW & $\begin{array}{l}\text { Face seal adaptor (threaded } \\
\text { riser adaptor) }\end{array}$ & FSA-400 & ? & no & & CARB EVR \\
\hline OPW & Manhole & $\begin{array}{l}\text { Conquistador, Fiberlite, } \\
\text { 104AOW-1200, 104C, }\end{array}$ & ? & no & & \\
\hline \multicolumn{7}{|c|}{ Overfill Prevention } \\
\hline OPW & Overfill prevention valve & \begin{tabular}{|l|} 
61SOM-412C-EVR, 61SOCM- \\
4000, 71SO, 71SO-T, 71SOM
\end{tabular} & E85 & no & & CARB EVR \\
\hline OPW & Overfill prevention valve & $\begin{array}{l}\text { 61SOC-4001, 61SOC-4011, } \\
\text { 61SOP-4002, 61SOP-4012 }\end{array}$ & E10 & no & & \\
\hline OPW & Float kit & $61 \mathrm{SOK}-0001$ & E10 & no & & \\
\hline OPW & Ball float vent valve & 21BV, 53VML, 30MV & E85 & no & & \\
\hline OPW & Drop tube & 61T, 61TC, 61TCP & E10 & no & & \\
\hline OPW & Drop tube & 61TSS & E85 & no & & CARB EVR \\
\hline OPW & Spill container (bucket) & 1-2100, 1SC-2100, EDGE & E100 & yes & no & CARB EVRa \\
\hline OPW & Spill container (bucket) & $1-2105,1-2200,101-B G 2100$ & E100 & yes & no & \\
\hline OPW & Tank bottom protectors & $6111,61 \mathrm{TP}$ & E10 & no & & \\
\hline \multicolumn{7}{|c|}{ Check Valve, Flexible Connectors, Vents } \\
\hline OPW & Flexible connectors & All & E100 & yes & no & SA \\
\hline OPW & Check valve & $70,70 \mathrm{~S}$ & E85 & yes & no & \\
\hline OPW & Pressure vacuum vent & $523 \mathrm{~V}, 623 \mathrm{~V}$ & E85 & yes & no & \\
\hline OPW & Pressure vacuum vent & 23 & $?$ & yes & & \\
\hline OPW & Vent & 514,515 & ? & $?$ & & \\
\hline \multicolumn{7}{|c|}{ Sumps } \\
\hline OPW & Dispenser sumps & FlexWorks & E85 & yes & no & \\
\hline OPW & Tank sumps & Fiberlite, FlexWorks & E85 & yes & no & \\
\hline OPW & Transition sumps & FlexWorks & E85 & yes & no & \\
\hline OPW & Sump accessories & FlexWorks & E85 & yes & no & \\
\hline
\end{tabular}




\begin{tabular}{|c|c|c|c|c|c|c|}
\hline Manufacturer & Product & Model & $\mathrm{E} \%$ & $\begin{array}{c}\mathrm{UL} \\
\text { Listed }\end{array}$ & $\begin{array}{c}\text { UL listed } \\
\text { for this } \\
\text { fuel }\end{array}$ & $\begin{array}{l}\text { Other } \\
\text { Approval }\end{array}$ \\
\hline Petroleum Containment & Sump-dispenser & CLE, DCL, EZ-PLUMB, MVR & $?$ & no & & \\
\hline Petroleum Containment & Sump-tank & 4200 & E100 & no & & \\
\hline Petroleum Containment & Sump-transition & all & $?$ & no & & \\
\hline Pneumercator & Magnetostrictive probe & $\begin{array}{l}\text { MP450S, MP451S, MP452S, MP461S, } \\
\text { MP462S, MP463S, MP464S } \\
\text { MP550S, MP551S, MP552S, MP561S, } \\
\text { MP562S, MP563S, MP564S }\end{array}$ & E100 & yes & no & \\
\hline Pneumercator & Leak sensors & $\begin{array}{l}\text { ES825-100F, ES825-100XF,ES825- } \\
\text { 100CF, ES825-200F, ES825-200XF } \square \\
\text { ES825-300F, ES825-300XF,ES825- } \\
\text { 300CF, ES825-400F, ES825-400XF } \square \\
\text { HS100D, HS100ND } \square \\
\text { LS600LD, LS600S, LS610 } \\
\text { RSU800-2, RSU801F, RSU810 }\end{array}$ & E100 & yes & no & \\
\hline Pneumercator & $\begin{array}{l}\text { Single/Multi-Point Level } \square \\
\text { Sensors }\end{array}$ & \begin{tabular}{|l} 
LS600, LS600F4, LS600M, LS600W, \\
LS600X \\
\end{tabular} & E100 & yes & no & \\
\hline Pneumercator & Mechanical Gauges & DR-1-10, P5, P14 & E100 & no & no & \\
\hline S. Bravo Systems & Fiberglass Fittings & $\begin{array}{l}\text { Series F, FF, FPE, FR, Retrofit-S, D- } \\
\text { BLR-S, D-INR-S, FLX, FLX-INR, FPS, } \\
\text { TBF }\end{array}$ & E100 & yes & no & \\
\hline S. Bravo Systems & Spill Buckets & B3XX & E100 & yes & no & \\
\hline S. Bravo Systems & Tank Sumps \& Covers & B4XX & E100 & yes & no & \\
\hline S. Bravo Systems & Transition Sumps & B5XX, B6XX, B7XX, B8XX & E100 & yes & no & \\
\hline S. Bravo Systems & $\begin{array}{l}\text { Under Dispenser Containment } \\
\text { Sumps }\end{array}$ & B1XXX, 7XXX, B8XXX, B9XXX & E100 & yes & no & \\
\hline Vaporless Manufacturing & Leak detector & $\begin{array}{l}\text { 99LD-2000/2200/3000 without stainless } \\
\text { steel tubing/fittings }\end{array}$ & E20 & yes & no & \\
\hline Vaporless Manufacturing & Leak detector & $\begin{array}{l}\text { 99LD-2000/2200/3000 with stainless } \\
\text { steel tubing/fittings }\end{array}$ & E100 & yes & no & \\
\hline Vaporless Manufacturing & Overfill prevention valve & $\begin{array}{l}\text { OPF-2/3 without stainless } \\
\text { steeltubing/fittings }\end{array}$ & E20 & yes & no & \\
\hline Vaporless Manufacturing & Overfill prevention valve & $\begin{array}{l}\text { OPF-2/3 with stainless steel } \\
\text { tubing/fittings }\end{array}$ & E100 & yes & no & \\
\hline
\end{tabular}




\begin{tabular}{|c|c|c|c|c|c|c|}
\hline Manufacturer & Product & Model & $\mathrm{E} \%$ & $\begin{array}{c}\text { UL } \\
\text { Listed }\end{array}$ & \begin{tabular}{|c|}
$\begin{array}{c}\text { UL listed } \\
\text { for this } \\
\text { fuel }\end{array}$ \\
\end{tabular} & $\begin{array}{l}\text { Other } \\
\text { Approval }\end{array}$ \\
\hline Veeder-Root & AST probe & Mag-FLEX & E15 & yes & no & \\
\hline Veeder-Root & Float kit & 846400 & E15 & yes & no & \\
\hline Veeder-Root & Magnostrictive probes & $\begin{array}{l}\text { Mag Plus Probe for Alternative } \\
\text { Fluids with Water Detection P/N } \\
846391-1 x x \text { or }-2 x x \text {, Inventory Only } \\
\text { Mag Plus Probe for Alternative } \\
\text { Fluids with Water Detection } \\
\text { P/N 846391-3xx }\end{array}$ & E20 & yes & no & \\
\hline Veeder-Root & Magnostrictive probes & $\begin{array}{l}\text { Mag Plus Probe for Alternative } \\
\text { Fluids without Water Detection } \\
\text { P/N 846391-4xx or -5xx, Mag Plus } \\
\text { Probe for Alternative Fluids } \\
\text { without Water Detection } \\
\text { P/N 846391-6xx }\end{array}$ & E100 & yes & no & \\
\hline Veeder-Root & Magnostrictive probes & $\begin{array}{l}\text { Mag-D Density Probe, MagPlus Leak } \\
\text { Detection Probe, MagPlus Inventory } \\
\text { Measuremeant Probe }\end{array}$ & E15 & yes & no & \\
\hline Veeder-Root & Mechanical line leak detect & Red Jacket FXV & E100 & yes & no & \\
\hline Veeder-Root & Phase separation float & Phase-2 & E15 & yes & no & \\
\hline Veeder-Root & Sensor-dispenser and sump & $\begin{array}{l}\text { Discriminating and Non } \\
\text { Discriminating Dispenser Pans and } \\
\text { Contaiment Sensors, Sump sensor } \\
\text { (piping), Mag Sump Sensor, Stand- } \\
\text { alone Dispenser Pan Sensor }\end{array}$ & E15 & yes & no & \\
\hline Veeder-Root & Sensor-dispenser and sump & Position Sensitive Interstitial Sensor & E85 & yes & no & \\
\hline Veeder-Root & Sensor-groundwater & Groundwater Sensor & E15 & yes & no & \\
\hline Veeder-Root & Sensor-tank & $\begin{array}{l}\text { Discriminating Interstitial Sensor } \\
\text { Double Wall Fiberglass, Interstitial } \\
\text { Sensors for Fiberglass Tanks, } \\
\text { Intersitial Sensors for Steel Tanks }\end{array}$ & E15 & yes & no & \\
\hline Veeder-Root & Sensor-tank & $\begin{array}{l}\text { Discriminating Interstitial Sensor } \\
\text { Double Wall Fiberglass, Interstitial } \\
\text { Sensors for Fiberglass Tanks-High } \\
\text { Alcohol, Interstitsial Sensors for } \\
\text { Steel Tanks-High Alcohol, } \\
\text { MicroSensor (steel tanks, fill riser) }\end{array}$ & E85 & yes & no & \\
\hline Veeder-Root & Sensor-vapor & Vapor Sensor & E15 & yes & no & \\
\hline Western Fiberglass & Co-Flex piping & all & E100 & yes & no & \\
\hline Western Fiberglass & Cuff fittings & all & E100 & no & & \\
\hline Western Fiberglass & $\begin{array}{l}\text { Sumps (tank, dispenser, } \\
\text { transition, vapor, vent) }\end{array}$ & all & E100 & yes & no & \\
\hline Western Fiberglass & $\begin{array}{l}\text { Co-flow hydrostatic Monitoring } \\
\text { systems }\end{array}$ & all & E100 & no & & \\
\hline
\end{tabular}




\section{Appendix F. Methods to Identify Underground Storage Tanks}

http://www.steeltank.com/Portals/0/TTNewsletter/September2012/TankTalk_September2012.pdf

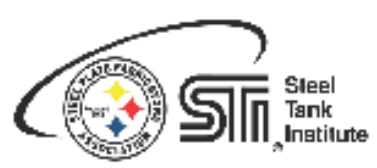

Tank Talk, September 2012

Identifying Buried Fuel Storage Tanks

by Bert Schutza, Tanknology, with contributions from Danny Brevard, ACCENT

How to identify the construction of your buried fuel starage tank

when original purchase documents are missing - a guidance tool offering some simple suggestions.

More than one method is often required to make conclusions specific to tank type:

1. Stick your tank to determine the tank diameter. Certain diameters of tanks between 6,000-gallon to 15,000-gallon capacity are indicative of steel tanks and some of the fiberglass reinforced plastic (FRP) tanks. 92" diameter tanks, for example, are almost always FRP, while 96" diameter tanks are normally steel.

a. Tank Diameter Measurement: Measure from bottom of tank to top of riser and then subtract the length of the riser.

2. Knowing the date of installation is a great tool for figuring out what type of steel tank you might have. This chart gives you important dates in the history of steel tank technology development:

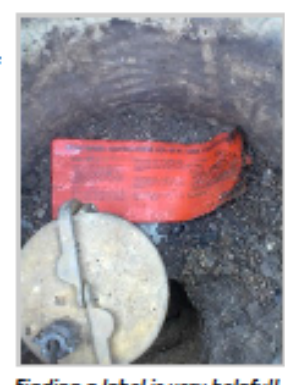

\begin{tabular}{|l|l|l|}
\hline Date & Event & Tank Type \\
\hline 1969 & $\underline{\text { Sti-P3 technology created }}$ & Cathodically Protected \\
\hline 1984 & STI Dual Wall Tank Standard published & \\
\hline$\underline{1987}$ & Original Association for Composite Tanks was formed & Composite \\
\hline 1990 & First STI standard for ACT-100 developed & Composite \\
\hline 1992 & STI adopted the Permatank technology & Jacketed \\
\hline 1996 & ACT-100-U created & Coated \\
\hline
\end{tabular}

3. Is your tank single wall or double wall? Double wall tanks will have an interstitial monitoring opening, which is often a $2^{\prime \prime}$ fitting. Double wall steel tanks have an access port directly down to the bottom of the steel tank, usually at the end of the tank. Some steel tanks, most often jacketed tanks, have a $2^{\prime \prime}$ interstitial riser pipe down through the inside of the tank, with tanks constructed since 1998 with the pipe in the longitudinal center of the tank. FRP tanks will usually have an access riser that goes down the tank top, and then circles the annular space around the tank. Some double wall FRP tanks have a liquid reservoir at the tank top, and

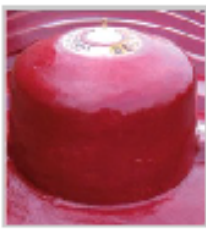

Liquid reservoir the interstice is full of brine solution.

944 Donata Ct. Lake Zurich IL 60047 847-438-8265 info@steeltank.com eSTI/SPFA 2011 


\section{Appendix G. Pipe Dope Diagram}

This diagram shows areas at a refueling station where pipe dope/pipe thread sealant might be used.

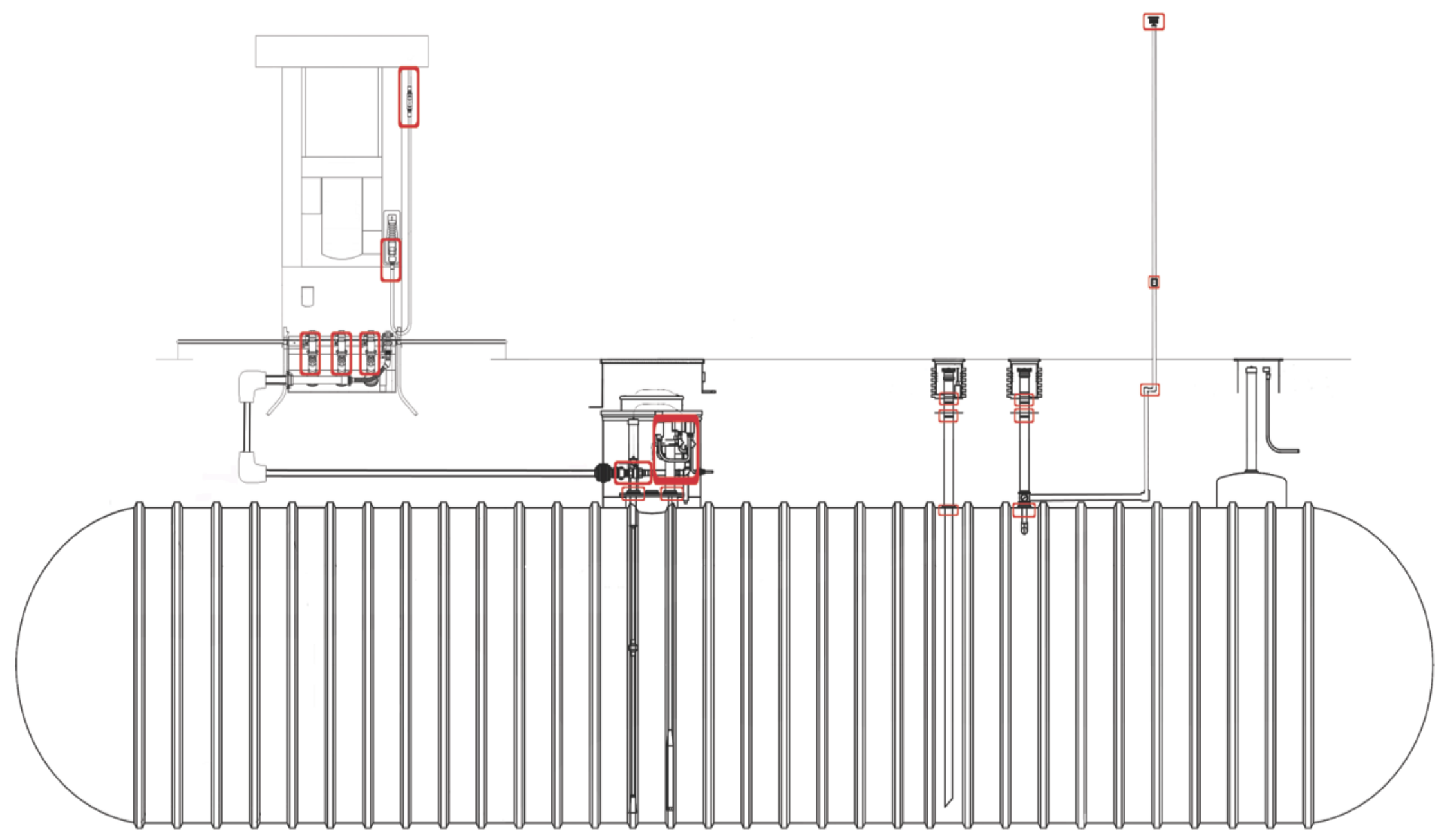

Diagram provided by Source North America, a fueling equipment distributor 